
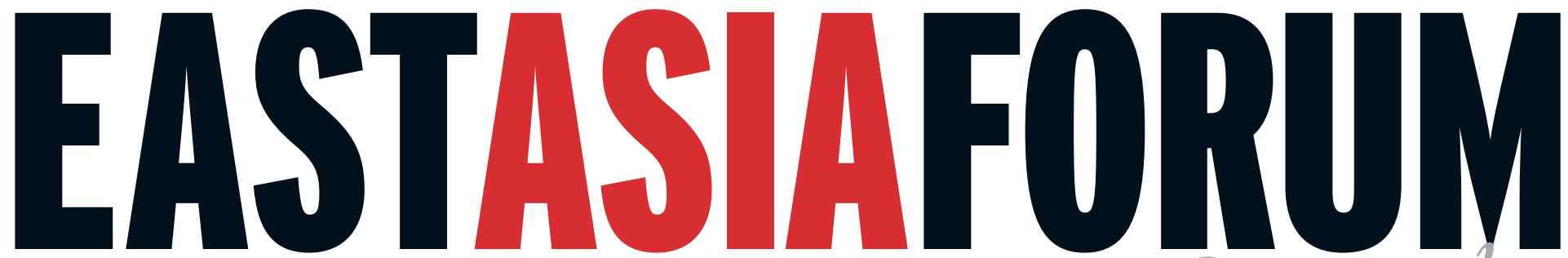

ECONOMICS, POLITICS AND PUBLIC POLICY IN EAST ASIA AND THE PACIFIC

Vol.13 No.4 October-December $2021 \$ 9.50$
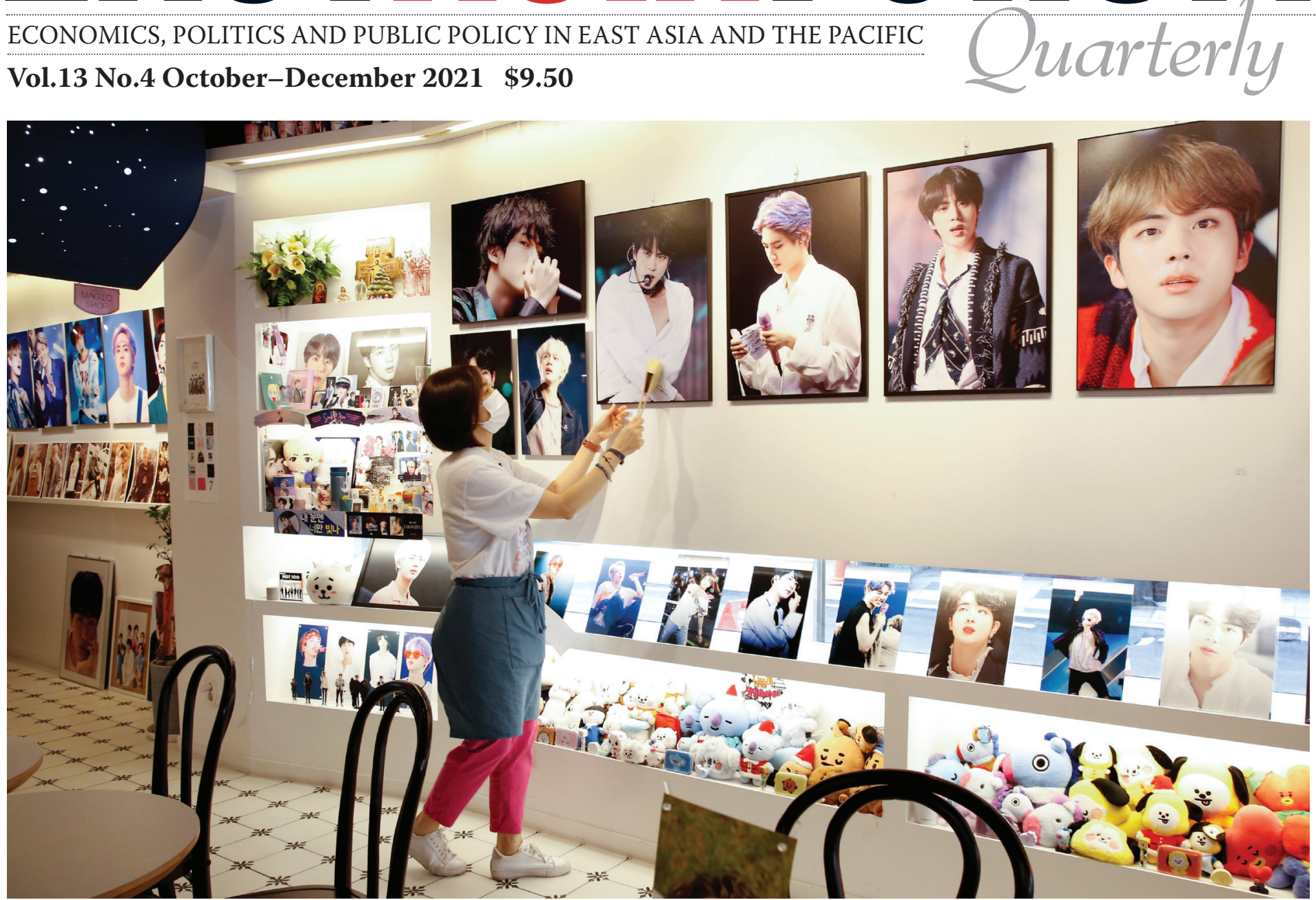

\title{
The Korean way
}

Andrei Lankov China's strategy for North Korea

Shin-wha Lee Middle power conundrum amid US_China rivalry

Jina Kim The future of defence transition

Hyung-A Kim What voters expect of the next president ... and more ASIAN REVIEW: Dino Patti Djalal on ASEAN and AUKUS 


\section{EASTASIAFORUM \\ . \\ ISSN 1837-5081 (print) \\ ISSN 1837-509X (online)}

\section{From the Editor's desk}

Surrounded by great powers, South Korea and North Korea have each weathered the upheaval of the COVID-19 pandemic in their own unique ways. Aspirations for greater autonomy and self-reliance are also driving significant changes to their political and security postures amid intensifying regional tensions.

This East Asia Forum Quarterly examines how the two Koreas are confronting the big challenges of our time. South Korea stayed open throughout the pandemic. It actively promoted its public health and advanced technology and green energy policies as a model of openness and innovation. Diplomatic engagement with the North continued even as South Korea embarked on its own major defence build-up. With South Koreans soon heading to the polls in a deeply polarised environment, the Moon Jae-in administration's achievements, shortcomings and unresolved tasks will be closely scrutinised.

Within South Korean society, dynamic and creative forces are emerging in surprising places: the military has become an important battleground for challenging homophobia, while street festivals celebrating LGBTQI+ culture now take place annually in the provinces as well as in Seoul.

Korean pop culture continues to be a juggernaut revealing new depths of talent in a variety of genres, though the pitfalls of tying Korea's national image to scandal-prone celebrity diplomacy are starting to emerge.

North Korea defied assumptions about its dependence on China by closing its borders at the start of the pandemic, even as those fleeing the regime embark on diverse journeys to a better life. The world is no closer to achieving denuclearisation of the North.

What lies behind this distinct, sometimes dysfunctional, but always dynamic 'Korean way'? To what extent has it contributed to South Korea's rise as an influential international actor on the world stage and North Korea's perseverance against the odds?

We survey some of the defining issues in contemporary Korean governance, economics, society and security and what makes the Korean way unique. They highlight the combination of pragmatism and ambition that makes the Korean experience so distinct.

Our Asian Review section looks at new tech dating, the marriage market and changing demography in China and the impact of AUKUS on Southeast Asia's regional strategic outlook.

\section{Peter K Lee and Ruth Barraclough}

CONTENTS

\section{ANDREI LANKOV}

Chinese aid strategy hinders goals on North Korea

\section{KUYOUN CHUNG}

Diplomatic dialogue needed for peace on the peninsula

\section{JINA KIM}

The future of South Korea's defence transition

\section{HYUNG-A KIM}

Voters expect fairness, integrity and COVID-19 recovery

\section{JOHN A. MATHEWS}

AND ELIZABETH THURBON

The Korean way to green growth

\section{DAVID HUNDT}

South Korea's developmentalist response to COVID-19

16 DINO PATTI DJALAL ASIAN REVIEW: ASEAN responses to AUKUS security dynamic

19 PAN WANG

ASIAN REVIEW: Lonely hearts look for love in China's revolutionary dating landscape

\section{TIMOTHY GITZEN}

The queer way of South Korea

\section{JAY SONG}

Escaping the North under Kim Jong-un

\section{SHIN-WHA LEE}

Middle powers face a conundrum amid US-China rivalry

\section{BO RAM KWON}

Putting South Korea's proactive national defence strategy in perspective

\section{CEDARBOUGH T. SAEJI}

Spinning South Korean cultural industry for soft power and nation building

COVER PHOTO: A K-pop cafe owner dusts photographs of her idols (Seoul 2020) Picture: Heo Ran / Reuters. 


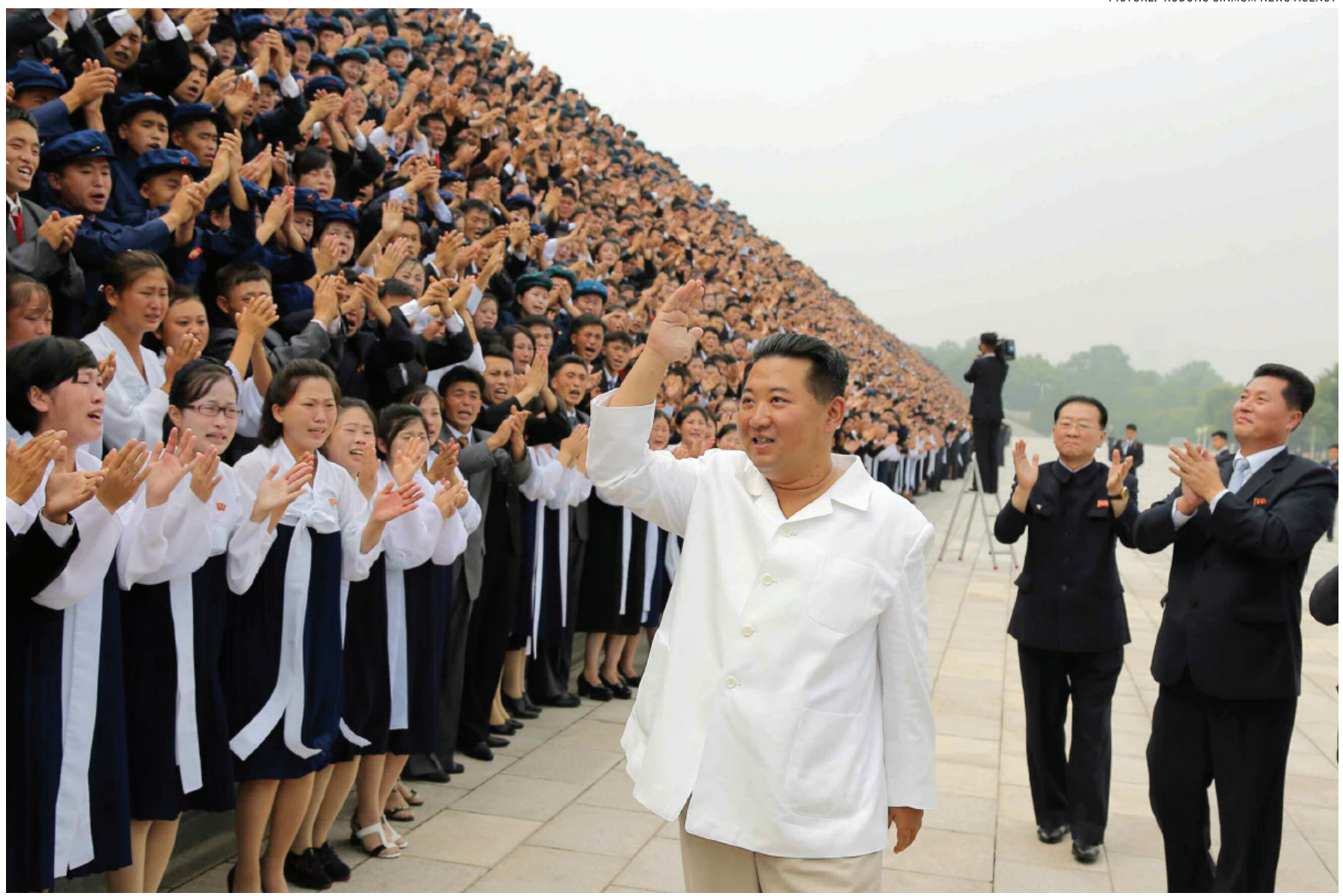

Kim Jong-un greets thousands of youth for North Korea's anuual Youth Day celebrations (Pyongyang, 31 August 2021).

\section{Chinese aid strategy hinders goals on North Korea}

\section{ANDREI LANKOV}

T IS possible that historians will

eventually see the 2018-2021

period as an important turning point in Korean history. In the space of a few years, the US-China confrontation has changed everything in Northeast Asia-and this change is likely to last for a long time.

The 'new Cold War', as this confrontation is sometimes known, has not altered China's strategic goals in Northeast Asia. But China is now willing to invest much more to achieve them.

What are these goals?

First, China needs a stable Korean peninsula. China does not want to deal with a Syria-style mess nearby especially one involving large stockpiles of nuclear weapons and other weapons of mass destruction.

Second, China wants Korea to remain divided. Currently, Korean unification is synonymous with the absorption of the destitute North by the rich South. For China, this would amount to a democratic and fiercely nationalistic state emerging on its border. This new state would most likely be an ally of the United States, 
EASTASIAFORUM EDITORIAL STAFF

Issue Editors

Peter K Lee, Research Fellow, United States Studies Centre, University of Sydney and Visiting Fellow, Korea Institute, ANU.

Ruth Barraclough, Director, Korea Institute and Head, Department of Pacific and Asian History, School of Culture, History and Language, ANU.

\section{Series Editors}

Peter Drysdale, Editor in Chief, East Asia Forum and Head, East Asian Bureau of Economic Research, Crawford School of Public Policy, ANU.

Shiro Armstrong, Director, AustraliaJapan Research Centre, and Editor, East Asia Forum, Crawford School of Public Policy, ANU.

\section{Editorial Staff}

Coordination: Arius Derr, Benjamin Yates, ANU.

Editing: Kira Atkins, Nicol Brodie, David Chieng, Alison Darby, Oliver Friedmann, Brandon Harrington, Grace King, Jade Lin, James Naylor-Pratt, Maya Salama, ANU.

Editorial Advisers: Max Suich, Peter Fuller.

Production: Niki van den Heuvel Email Peter.Drysdale@anu.edu.au, Shiro.Armstrong@anu.edu.au.

Views expressed are those of individual authors and do not represent the views of the Crawford School, ANU, EABER, EAF, or the institutions to which the authors are attached.

\section{ANU $P R E S S$}

Published by ANU Press The Australian National University Canberra ACT 2601, Australia Email: anupress@anu.edu.au Web: http://press.anu.edu.au with potential for US troops to be stationed on its soil unless withdrawal were part of a grand settlement.

China's third goal is the denuclearisation of the Korean peninsula. The North Korean nuclear program undermines the nonproliferation regime, which gives massive advantages to the 'nuclear five', including China.

The first and second goals, while not the same, are close enough to be fused into one overarching aim: to maintain the status quo. This is especially pronounced as China enters a longterm confrontation with the United States. The denuclearisation goal is merely a distant third in the list.

The first Cold War lasted for four decades. Nobody knows how long the 'second Cold War' will continue. There may be ups and downs, periods of detente and of crisis. But no signs of a solution or lasting compromise are in sight.

Until a few years ago, China was remarkably ambivalent about the future of North Korea. As recently as late 2017, Chinese diplomats not only supported the ultra-tough US sanctions on North Korea in the United Nations, but also pressed Russia, their junior ally, to vote in favour of these sanctions.

These are positions of the past. While China does not violate the United Nations Security Council (UNSC) sanctions blatantly, it is willing to turn a blind eye on smallscale violations, use all available loopholes to support North Korea and sometimes ship forbidden items to the state if the chances of being caught are low. Even now, when North Korea, wary of the impact of COVID-19, has cut itself off from the outside world, Chinese aid keeps coming quietly. While the provisions of food aid are not in violation of UNSC resolutions, shipments of fuel are, including

That North Korea is working hard to build disinfection and quarantine centres to process Chinese aid, suggests much larger volumes are expected.

In the current situation, China, despite its dislike of North Korea's nuclear program and generally critical attitude to the Kim Jong-un regime, has no choice but to keep North Korea afloat. North Korea's stability is a paramount concern to Beijing and this is likely to remain the case in the foreseeable future.

From the international community's point of view, this is both good and bad.

The Chinese decision to take responsibility for keeping North Korea afloat means that from now on, the North Korean government can rely on 'dole payments' from China. These welfare cheques will not bring industrial growth to North Korea but will ensure against a major outbreak of famine. As long as the North Korean people receive enough to survive and officials are reasonably rewarded for loyal service, North Korea is likely to remain stable and above all, China wants stability.

in Beijing's view, denuclearisation decisively takes a back seat to the maintenance of stability on the peninsula 
Pyongyang has fewer reasons to worry about its outdated and inefficient economic system. The first years of Kim Jong-un's rule were marked by quiet but radical economic reforms which largely emulated what China did in the 1980s, albeit without any attempts at political openness. Since 2018 these reforms have been increasingly obstructed and partially rolled back. More economic freedom can be dangerous for domestic stability as it allows North Koreans to be less dependent on the government.

Reforms once constituted a necessary compromise that Kim Jongun understood: to stay in power, he needed to ameliorate the economic problems of his country. Now, he has no reason to worry. Chinese aid ensures against dramatic crises, so for the time being it is better not to play with the system. In building its relationship with Pyongyang, Beijing has tempered North Korea's penchant for nuclear warnings. Unlike his predecessors, US President Joe Biden was not welcomed into office by North Korean nuclear tests and intercontinental ballistic missile launches. China's unhappiness about North Korean provocations, which attract unnecessary attention to the region and justify the US military presence there, has persuaded the North Koreans to keep quiet.

North Korean society will be even more closed and controlled than before, as people are ignorant about alternatives to the system and deathly afraid of their government. The economy will remain inefficient, but if it can count on regular shipments of Chinese aid it is unlikely to become politically dangerous. As long as Chinese dole payments continue arriving, North Korea will find itself in a time warp-for years or even decades.

But North Korea's nuclear weapons are here to stay. China's leverage is not strong enough to push North Korea into denuclearisation-and in Beijing's view, denuclearisation decisively takes a back seat to the maintenance of stability on the peninsula. A meaningful compromise that reduces North Korea's nuclear capacity does not appear likely under this new arrangement. EAFQ

Andrei Lankov is Professor at Kookmin University, Seoul, and Director of NK News.

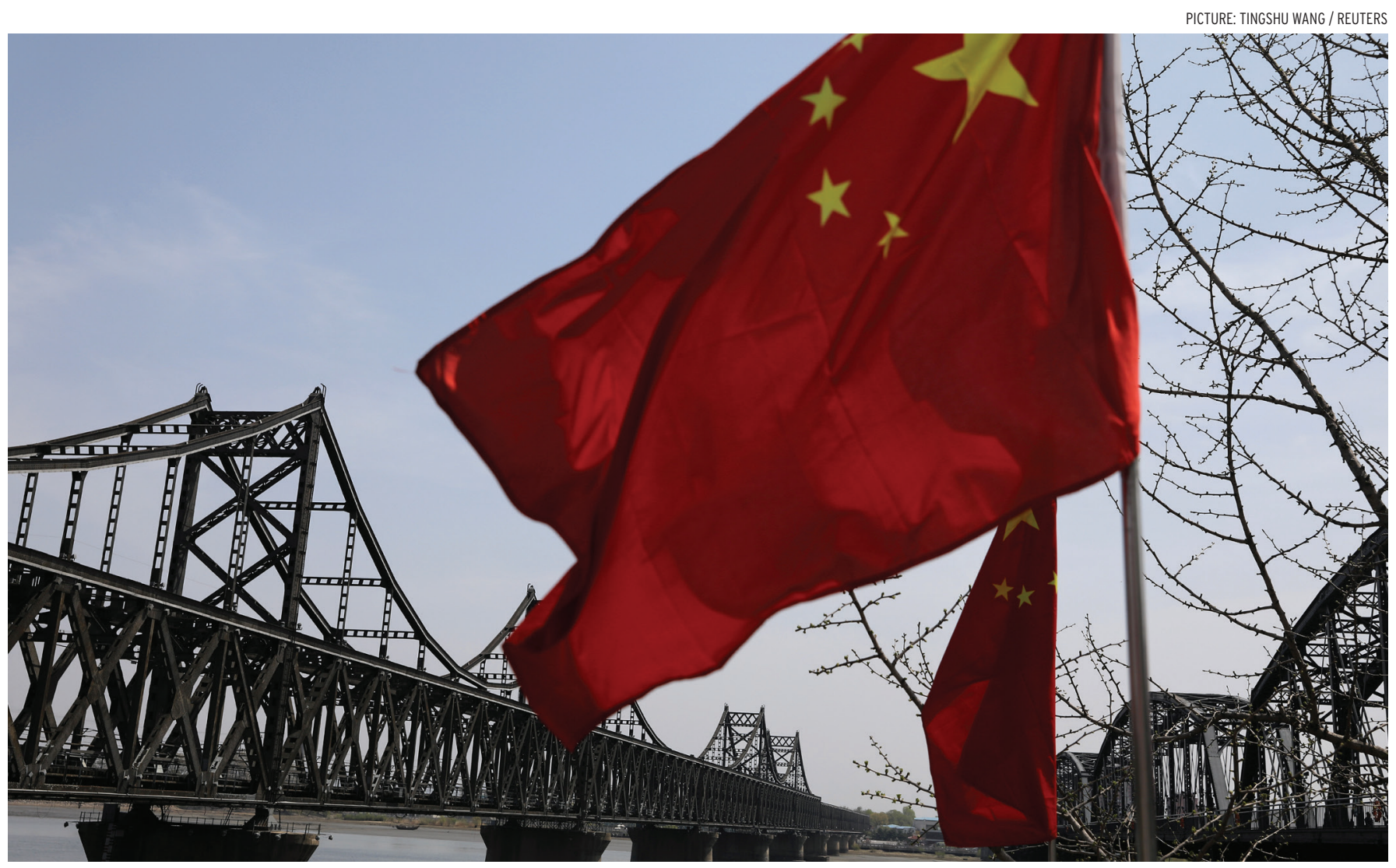

A Chinese national flag flutters near the Friendship Bridge and Broken Bridge over the Yalu River, which separates North Korea's Sinuiju from China, in Dandong, Liaoning province (21 April 2021) 


\section{Diplomatic dialogue needed for peace on the peninsula}

KUYOUN CHUNG

A LTHOUGH only a few months remain before the end of Moon Jae-in's presidential term, Seoul is relentlessly pursuing a declaration of an end to the Korean War between Washington and Pyongyang and attempting to revitalise momentum for a denuclearisation dialogue. But the United States and South Korea seem to perceive the tactical value of this declaration differently and are not on the same page over the scenarios they might confront once they issue it.

As a step towards a peace agreement, the Moon administration intends to build trust between the United States and North Korea with the declaration to restart a denuclearisation negotiation. Critics stress the significance of legal

\section{China's lack of}

\section{cooperation in}

\section{denuclearising North}

\section{Korea will most likely}

meet a thickening

web of allied security

cooperation around the

Korean peninsula enforcement nested in the declaration. Without legal enforcement that 'ends the Korean War', as President Moon has suggested, the declaration will not reduce the threat perception in Pyongyang of US 'hostile policies' or catalyse the momentum for a nuclear dialogue.

Legal enforcement, on the other hand, requires discussion of the dissolution of United Nations Command, withdrawal of US forces from the Korean peninsula and revision of the South Korea-US Mutual Assistance Treaty. These are scenarios that the allies are not ready to countenance yet.

It is one thing, of course, for South Korea and the United States to agree on issuing the end-of-war declaration. It is another to persuade the North to accept it. North Korea has already declared itself as a nuclear state in its constitution, while China, one of North Korea's few benefactors, prioritises the stability of the Korean peninsula over the denuclearisation of North Korea. The North tactically aligns with China whenever US-North Korea talks fail and even more in a time of US-China rivalry.

Seoul and Washington must take those attitudes as the premises on which they can devise a more realistic strategy for denuclearising North Korea. Contrary to the Moon administration's thinking, the end-ofwar declaration is unlikely to linearly lead to a peace regime on the Korean peninsula. US President Joe Biden needs to accept that denuclearisation is a long-term goal that requires a focus on strengthening deterrence to adapt the North's ever-developing nuclear and missile capabilities in the region while reassuring allies about that approach.

Conservatives in South Korea have serious concerns about the North's potential for nuclear coercion and nuclear-backed military adventurism. This has even led the conservative People's Power Party's presidential candidate, Yoon Seok-youl, to support redeployment of tactical nuclear weapons on the Korean peninsula to maintain the 'balance of terror' vis-à-vis North Korea. This long-term investment to strengthen a deterrence posture on the Korean peninsula is intended to change the strategic calculation of the North and China and be more effective than signing a revocable declaration in forging the structure of collective action in which no one has the incentive to deviate.

Increasing joint military exercises to maintain seamless coordination between allies and improving defence infrastructure with technological innovation would reduce the risk of a North Korean miscalculation based on its nuclear and missile capabilities. Strengthening deterrence on the peninsula will signal to China that the North's nuclear and missile capabilities 


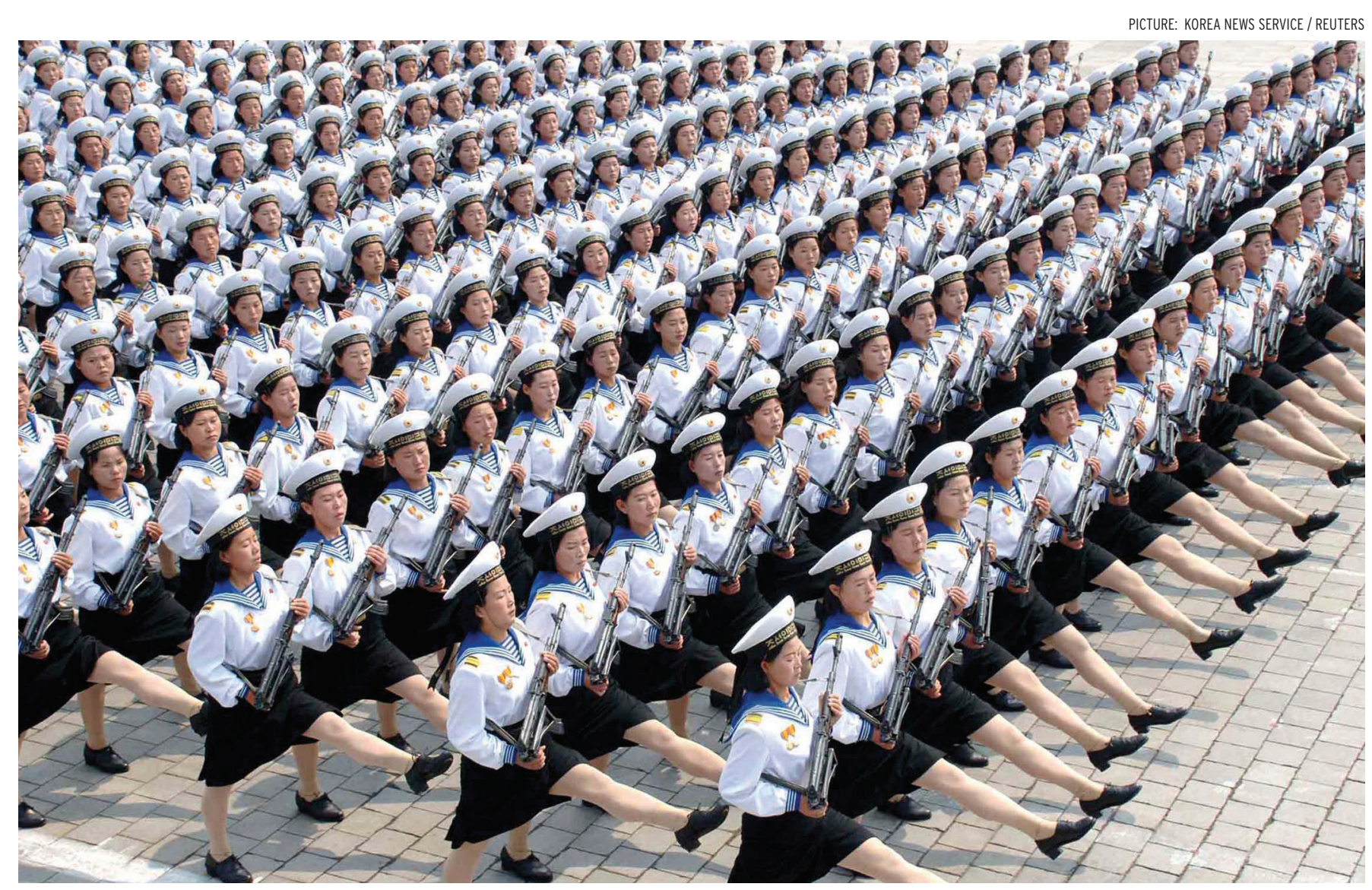

North Korean female sailors conduct close-order manoeuvers during a military parade in central Pyongyang (April 2007).

will not be tolerated as a fait accompli.

China's lack of cooperation in

denuclearising North Korea will most likely meet a thickening web of allied security cooperation around the Korean peninsula. Security cooperation, such as maritime surveillance to prevent ship-to-ship transfers with North Korean vessels, serves as a good area whereby to mobilise multilateral efforts. This has already seen individual action taken by Japan, Canada, New Zealand, France and Australia.

Denuclearising North Korea requires more than shoring up deterrence, which might harden its resolve and increase tension on the peninsula. The United States and South Korea need to keep open opportunities to engage North Korea's ruling elites in the long term.
Engagement does not have to involve a bold peace offensive, nor does it necessarily have to be in sync with the progress of denuclearisation negotiations. But it does need to persuade the North's elites that maintaining a nuclear state will isolate their country and limit its potential for future economic growth. This engagement should include an opportunity for reciprocation by the North, based on the confidencebuilding measures agreed upon during the Moon administration, such as dismantlement of guard posts along the Demilitarized Zone or restoration of cross-border hotlines. Establishing a liaison office between the two Koreas and the United States would further institutionalise reciprocity and reduce unnecessary tension.

Peaceful denuclearisation is still plausible, but only in the long term. 'Peaceful' indicates the progress of denuclearisation in a strategic environment in which nuclear coercion and militarised crisis escalation become costly for the North. Shaping such a strategic environment is the precondition in conducting nuclear diplomacy with North Korea. Consistently sustaining an opportunity for reciprocation will not only reduce tension but also provide North Korean elites with exposure to the world and narrow the alternatives within which they can reorient national strategy to survive.

\section{Dr Kuyoun Chung is an Assistant Professor in the Department of Political Science at Kangwon National University.}




\section{The future of South Korea's defence transition}

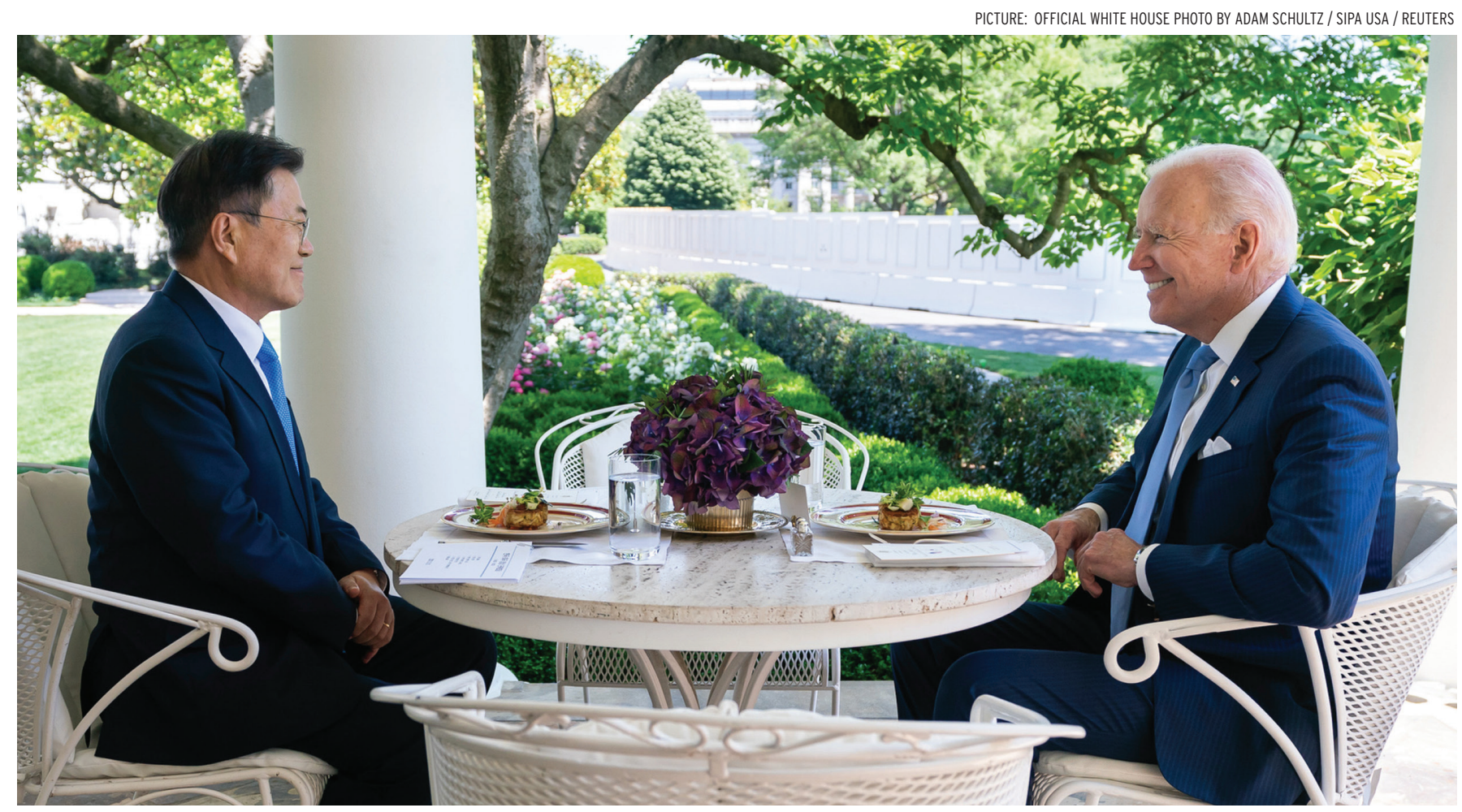

South Korean President Moon Jae-in and US President Joe Biden enjoy lunch on the Oval Office Patio of the White House (21 May 2021).

JINA KIM

N SOUTH KOREA, presidential
election fever is heating up. Key
candidates from the conservative
People Power Party and the liberal
Democratic Party of Korea are
presenting their blueprints for the
future of South Korea's security and
defence.
Lee Jae-myung, the ruling
Democratic Party's presidential
candidate, vows to swiftly realise
the transition to operational control
(OPCON) agreed to by South Korea
and the United States, thereby
consolidating the alliance relationship.
At the meeting with US Assistant

Secretary of State for East Asian and Pacific Affairs Daniel Kritenbrink on 11 November he stressed developing the alliance into a global partnership. Yoon Seok-youl, the conservative People Power Party's presidential candidate, prefers to strengthen a strategic alliance with the United States and calls for South Korea's active participation in efforts to build a global coalition. Although the two camps diverge on the issue of North Korea and China, they support defence innovation and South Korea's active participation internationally.

Regardless of who takes power in
2022, the trend of increasing South Korea's defence spending will continue and projects to enhance its military capabilities through defence reform will show continuity.

South Korea's pursuit of Defense Reform 2.0 aims to revolutionise the South Korean armed forces as an innovative force to meet future security threats. Defense Reform 2.0-launched in the early days of the Moon administration to improve the defence reform plan of the previous government-should encourage a more effective and capable South Korean military force that not only 
has increased deterrence capabilities against North Korea but also is able to effectively respond to dynamic changes in the security environment. This is intertwined with the goal of exercising wartime OPCON, which has so far been delegated to American Combined Forces Command (CFC). The OPCON transition requires significant force improvement so that South Korea can build core military capabilities to lead a combined defence force and bear a primary responsibility for its own defence against North Korea's ever-increasing military threats. Though talk of this transition has gone through ups and downs because of threats from the North or rapprochement between the two Koreas, South Korea is driven by a desire for autonomy within the alliance system and a greater role internationally to match its economic and military heft.

So, how far has South Korea come in its pursuit of OPCON transition and defence reform?

The Moon Jae-in administration is pushing for an early OPCON transition, but as the United States requires sufficient verification and certification, it is unclear when this will happen. Completing the steps necessary for certification assessment seems remote. The US position is that 'any decision regarding OPCON transition will be an alliance decision and is based on bilaterally agreed conditions and not a timeline'. In addition, the United States insists that the conditions agreed upon must be completely satisfied. This includes ensuring that South Korea's military becomes capable of leading the CFC and taking the initial response to a North Korean nuclear missile attack. Some experts in South Korea argue that these conditions are excessive.

It is also ambiguous whether all
155 assigned mission essential tasks (MET) should be fulfilled or whether priority METs can be satisfied with the rest passed conditionally. In any case, to ensure that a future CFC led by a South Korean general can successfully accomplish its assigned mission, South Korea needs to push for the acquisition of Intelligence, Surveillance, and Reconnaissance (ISR) assets and intensive training to secure its readiness. As an annual joint military training exercise was reduced due to COVID-19, plans to verify the operational capability of the CFC were also affected. The United States could not assess its full operational capability, which is phase two of the three-phase verification process required for the transition.

$\mathbf{T}$ HE OPCON transition will mark a turning point for South Korea's defence system, as will ongoing defence reform. The 2022-2026 Mid-term Defense Plan announced by the Ministry of National Defense set a total budget of 315.2 trillion won (US $\$ 270$ billion) for the next five years with an average annual rate of increase in spending of 5.8 per cent. A total of 106.7 trillion won (US $\$ 90$ billion), with an average annual increase of 8.3 per cent, will be invested in force improvement programs, which aim to apply state-of-the-art technology to all areas of national defence. There were plans to develop longer-range and more precise missiles by lifting the missile guidelines restrictions at the US-South Korea summit in May 2021. South Korea may also deploy a light aircraft carrier to boost its capability to respond to various security threats in the region.

An array of programs is being implemented to secure the required core military capabilities for the OPCON transition. South Korea is strengthening communication capabilities and looking to acquire military reconnaissance satellites, unmanned air vehicles and Baekdu surveillance aircraft. It is enhancing its precision strike capability by securing long-range air-to-ground missiles and new-type missiles as well as upgrading the Patriot and Cheolmae-II missiles. And the Korea Air and Missile Defence is being strengthened by fielding ballistic missile early-warning radar systems.

Seeking advances in ground, sea and air operational capabilities is desirable but also invites tit-for-tat actions between the two Koreas. North Korea criticises South Korea's military build-up as unnecessarily destabilising regional security. As North Korea claims to have built nuclear weapons because of its inferiority to conventional capabilities, South Korea's increasing military spending for defence modernisation can encourage the North to seek balancing behaviours. The problem is that a stable security environment on the Korean peninsula is inevitably a prerequisite for South Korea to make a greater contribution to the global partnership. But, since the South Korean military has a longterm plan for building a strong elite force prepared for the future security environment, investment in defence reform is likely to continue.

When the time is right, South Korea will consider negotiations with North Korea. How each side's search for offsets may feed an arms race on the Korean peninsula and how they can best manage stability and maintain confidence in the sufficiency of their forces will be up for future discussion.

Jina Kim is Professor in the Division of Language and Diplomacy at Hankuk University of Foreign Studies. 


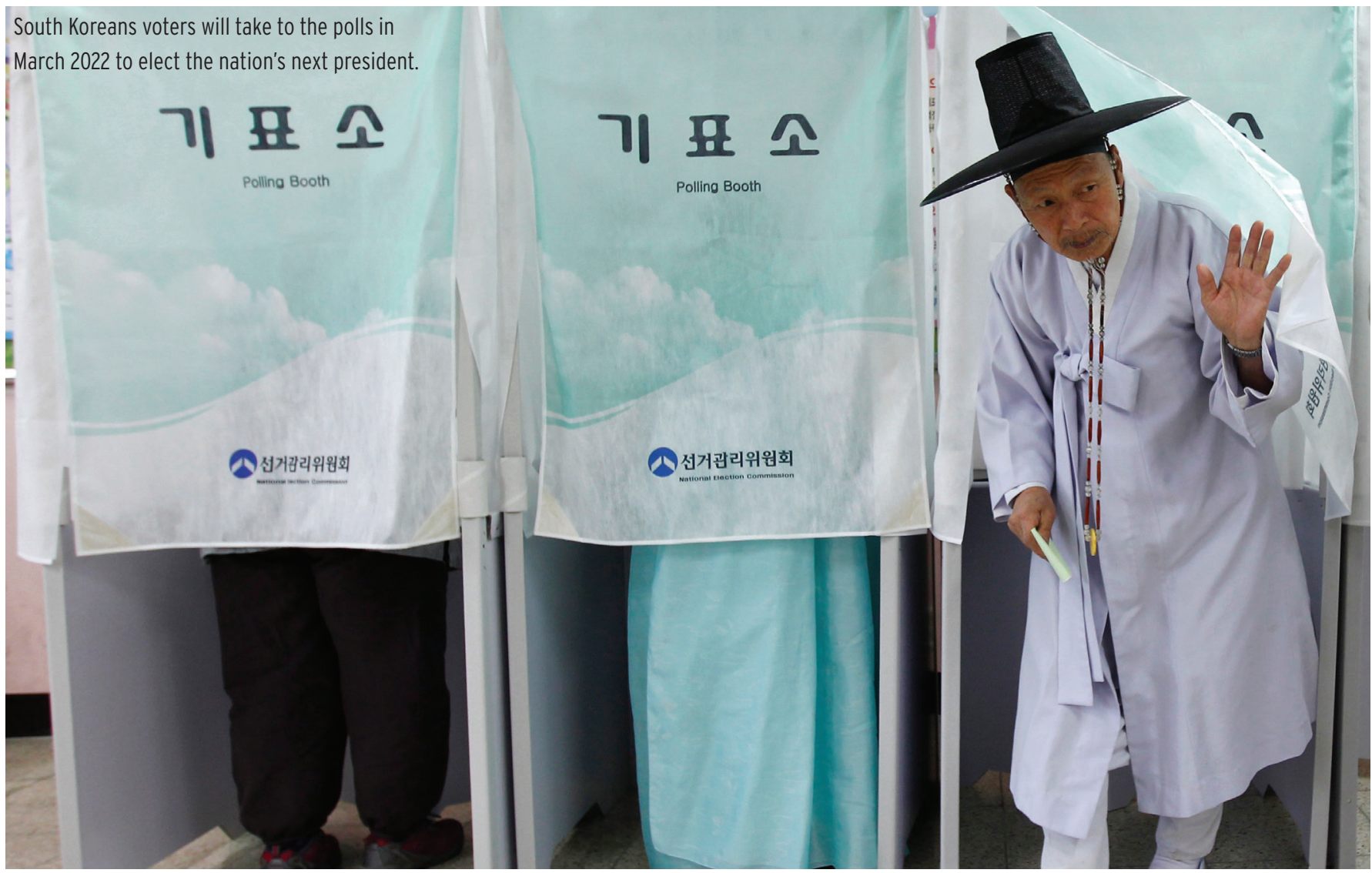

\section{Voters want fairness, integrity and COVID-19 recovery}

HYUNG-A KIM

W

ITH less than four months to South Korea's presidential election on 9 March 2022, the contest is turning into a quasi-life-or-death round of Squid Game amid scandals involving the ruling Democratic Party's (DP) frontrunner Lee Jae-myung, former governor of Gyunggi province, and the main opposition People Power Party (PPP) frontrunner Yoon Seokyoul, former prosecutor-general. Both Lee and Yoon are campaigning on fairness and justice, prompting political cynicism especially among young people.

A recent Gallup survey (over 2-4 November 2021) suggests that 57 per cent of respondents reckoned that 'it is better to elect an opposition candidate to replace the government.' At the same time 33 per cent thought that 'it's better for the ruling party candidate to be elected to maintain the current administration, a 24 per cent gap-the largest in Gallup surveys since the inauguration of the Moon Jae-in administration. But in the same survey, in answer to a free question about the preferred political leader, the ruling DP candidate Lee Jae-myung was ahead with 26 per cent, above the conservative PPP candidate Yoon Seok-youl with 24 per cent.

This contradiction has dramatically resolved itself in the latest Gallup survey (over 16-18 November). In this survey, 42 per cent preferred Yoon over Lee (with 31 per cent) and two other presidential candidates from minor opposition parties, Ahn Cheolsoo (7 per cent) and Shim Sang-jung (5 per cent). The two surveys reflect the 
Korean voters' anger about the failures of Moon Jae-in's liberal administration and their doubts about the scandals surrounding Lee and Yoon.

Three key issues are likely to have a major influence on how the election turns out.

The biggest is voter demand for fairness in Korean politics and society. President Moon Jae-in's widely-perceived 'one-way' national management, combined with his hypocritical 'rules for thee, not me' are exemplified by his tight control over real estate investment for South Korean citizens while members of his own government have been engaged in wild land speculation. The revolt of young Korean voters at the April 2021 mayoral by-elections, in which there were sweeping victories by the opposition PPP, represented a clear warning for the 2022 presidential race.

The Cho Kuk scandal, which forced the then justice minister to resign after his wife was found to have rigged the university admission process in favour of their daughter, particularly incensed young voters who struggle for upward mobility in Korea's rapidly ageing and competitive society. They demand fairness in the processes that determine advancement.

$\mathbf{T}$ HERE are vast generational differences, not only in political preference and narrative, but in what constitutes fairness within South Korean society. Voters in their 40s and 50s, beneficiaries of Korea's rapid industrialisation, for example, focus on fair outcomes. Fierce generational clashes are expected in the presidential election, especially over the ability to restore fairness and justice in South Korean democracy.

The second major issue is the competence of both Lee Jae-myung and Yoon Seok-youl to assume the presidency. Both project a strong image of fairness, but neither has parliamentary experience. Lee pledges a universal basic income and Yoon promises to restore justice and the rule of law through regime change. Neither Lee nor Yoon have clean track records on these fronts.

Lee narrowly secured a party primary victory over former prime minister Lee Nak-yon in October amid a snowballing land development scandal in Seongnam, Gyeonggi province while he served as Seongnam mayor. Lee's defiant response to his alleged involvement in this scandal led many supporters of the ruling DP to turn their backs on both the DP and Lee and reduced his cache of voter 'goodwill'. Since his nomination, the DP's approval rating in Korea's southwest-a historic left strongholdhas plunged by 13.9 percentage points from 63.3 per cent a week earlier to 49.4 per cent. Lee's 'approval' rating is stuck at 32 per cent, while his 'disapproval' rating rose to 63 per cent from 60 per cent a month earlier, according to Gallup.

Yoon is no less entangled in scandal. Allegations of abuse of power have emerged about his time as the country's top public prosecutor. As a newcomer to politics, he doesn't appear to appeal to young voters either, with many of the under 30s preferring Yoon's opponent, a veteran politician, in the presidential primaries.

The third and arguably most sensitive issue is COVID-19 management. Despite the Moon administration's early success at containing the virus, daily cases have skyrocketed, with 2618 deaths and 337,679 new cases recorded in October. In November with almost 79 per cent of the population fully vaccinated, the Moon administration rolled out a series of measures under its Living with COVID-19 plan to nudge the country back to normalcy. In less than three weeks, however, the country's number of daily COVID-19 confirmed cases reached almost 4000 while the number of severely ill patients reached an all-time high of 549 on 23 November. The Moon administration is now reported to be 'considering an emergency plan' to deal with the crisis.

Unless Moon's Living with COVID plan succeeds, the public backlash against the government and the ruling Democratic Party will be costly given the host of other problems that South Koreans have faced over the past five years.

Which factors ultimately dominate the outcome in the election is difficult to predict but, if the recent past is any indication, South Korea's middle class, especially young swinging voters in their 20s and 30s will make the final judgement. The outcome is likely to lean towards the candidate who captures the voters' demand for fairness and justice. EAFO

Hyung-A Kim is Associate Professor of Korean Politics and History at the School of Culture, History and Language, The Australian National University.

\section{EASTASIAFORUM} OUR NEXT ISSUE . . .

\section{Digital economic integration}

www.eastasiaforum.org 


\section{The Korean way to green growth}

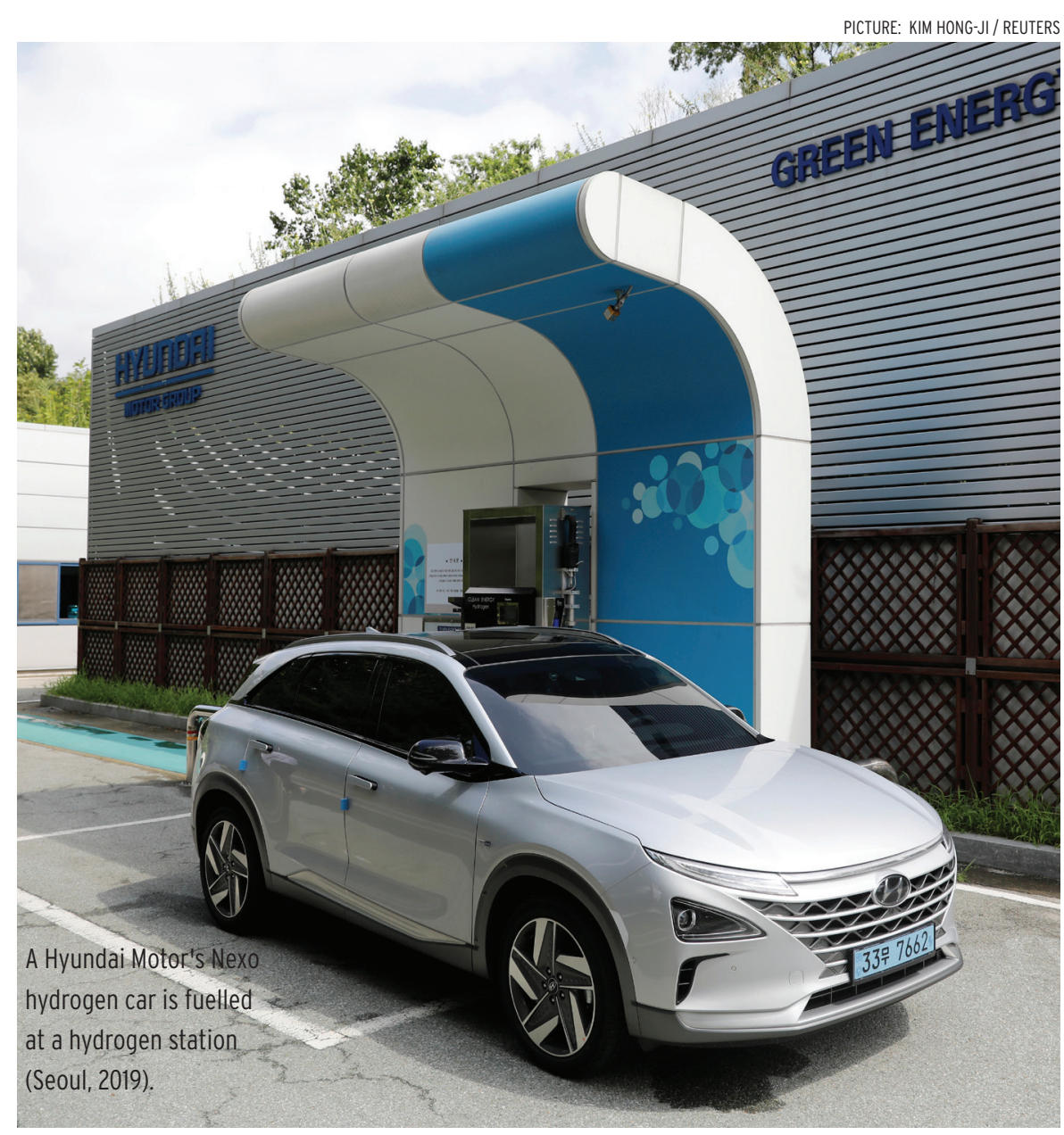

JOHN A. MATHEWS

AND ELIZABETH THURBON

T HE three major East Asian economies-South Korea, Japan and China-share a common approach to their climate strategy. Unlike Western countries, which place primary emphasis on reducing carbon emissions, the East Asian trio pursue a climate-focused industrial policy. Their emphasis is on building new green industries and phasing out dirty industries as they transition away from reliance on fossil fuels.

As successful latecomers to industrialisation over the course of the 20th century, first Japan, then South Korea and China built vast energy systems powered by fossil fuels as engines of their industrial prowess. Now in the 21st century they are grappling with the process of dismantling these legacy systems and building new green industrial powerhouses.

Like its East Asian neighbours, South Korea was relatively slow to turn away from fossil fuels and start building a new energy system based on wind and solar power. But once the transition began, it was pursued with dedication and ambition, drawing on the same developmental mindset that drove the approach to fossil-fuelled industrialisation in the latter half of the 20th century. In this sense, to understand the Korean way towards green growth, one must first understand the Korean way of rapid economic catch-up.

Over the second half of the 20th century, South Korea was the second major East Asian nation to utilise catch-up strategies of technology leverage, emulating Japan. It built its first manufacturing industries in clothing and textiles, then moved on to simple electronics and white goods before tackling heavy and chemical industries in the 1970s, focused on the automotive sector. In the early 1990s, the roads were full of locally-made cars-Hyundais, Kias-a visible sign of a strong state at work in building and protecting a new industry.

The Korean way was always about accelerated catch-up, or what some called 'compressed development'. South Korea took bigger risks and went for bigger rewards. It was as scholar Jung En-woo called it, a 'race to the swift'. South Korea drove its economy in catch-up mode harder than anyone else, driven by high levels of indebtedness.

The transformation was evident in the career of Lee Byung-chull, founder of Samsung, who had been branded as a war profiteer during the Korean war but at his death was hailed as a national hero. He had taken Samsung 
from a simple sugar and food producer to an international giant in the most advanced aspects of semiconductor production at the core of the electronics and IT industries. He was also guiding Samsung to become an automotive company that would rival and perhaps outclass Hyundai, only to see these plans cut short by the 1997 Asian financial crisis.

Perhaps the most famous of the big bets placed by the South Korean policymaking elite was to back the telco standard CDMA (Code Division Multiple Access), introduced as a 3G technology standard for mobile phones by the US firm Qualcomm. The Korean state actively backed this as one of the first movers, inducing Samsung and others into the nascent market. This choice propelled the South Korean firms to become telco giants and created a long war with Qualcomm over payment of royalties that saw the South Korean side ultimately prevail. South Korea used all available state resources to ensure that CDMA was adopted as a standard internationally, helping to propel the mobile tech revolution.

I N THE 21st century, South Korea is maintaining the developmental mindset of its glory days as a rising techno-power. However, the focus of its developmental ambitions has shifted from promoting the fossilfuel intensive industries of the past to the new, clean green industries of the future. Since the mid-2000s, this shift has been seen as an imperative by successive Korean governments, which have grown increasingly anxious about the major economic, environmental and political costs of their countries' overwhelming reliance on fossil fuels.

Korea's continued developmental ambitions are clear in the Moon Jaein administration's set of strategies announced as part of the Digital New Deal, combined with a suite of strategies labelled the Green New Deal.

South Korea's Green New Deal exemplifies the trends of the East Asian clean energy transition and displays all the accelerated ambition of the Korean way. The Green New Deal contains anticipated strategies like provision of improved green infrastructure and green buildings, as well as a swing towards renewables as the country seeks an exit from dependence on fossil fuels. But it is in building a new automotive sector based on electric vehicles, encompassing battery electric vehicles as well as hydrogen fuel cell electric vehicles, that South Korea's ambition is most evident.

In an extension of the developmental mindset from conventional industry to green industry and green growth, the South Koreans are betting big not just on battery-powered vehicles but also on hydrogen fuel cell vehicles, where Hyundai already rivals Toyota as a world-leading producer and pioneer. The stakes are enormous, with Hyundai promising to become one of the world leaders in taking vehicles to the next level of green electrification. The government's ultimate aim is to establish Korea's leadership-especially over China-in the new, technology intensive, export-oriented, job creating industries of the future. Economic dynamism, job creation, and pollution control are seen as essential to maintaining the government's political legitimacy.

The energy component of the Green New Deal includes raising the level of renewable energies, building out the smart grid, promoting renewables such as large-scale offshore wind power and expanding the supply of electric and fuel cell electric vehicles (1.3 million electric and 200,000 fuel cell vehicles by 2025). These are ambitious targets that represent strong intervention in the market by the Korean state.

Key to the Korean way is placing big techno-economic bets before the market and then using state resources to bring about the desired market shift. Applied to climate sensitive areas like the building of renewable energies and phasing out fossil fuels, South Korea's strategic approach is to focus on creative destruction-building the new while dismantling the old - as an industry strategy, not just as a pure play to reduce carbon emissions.

The result is the same-reducing carbon emissions. South Korea is building green industries with lower carbon emissions, but the emphasis in policy is all about the industrial transformation that drives it. This is an extension of the wellestablished developmental mindset, or developmental environmentalism, now applied to climate goals.

The Korean way to the green transition, viewed as the next great transformation of industrial capitalism, promises to give developing countries worldwide a chance to catch-up through developmental-environmental strategies. South Korea's competitive dynamic with China and its ambition to reduce carbon emissions is driving the formulation and application of these strategies. East Asia is moving to become the fulcrum of the next great industrial transformation. EAFO

John A. Mathews is a Professor Emeritus in the Macquarie Business School at Macquarie University.

Elizabeth Thurbon is a Scientia Fellow and Associate Professor of International Political Economy in the School of Social Sciences, UNSW Sydney, and an Australia-Korea Fellow at The Asia Society. 


\section{South Korea's developmentalist response to COVID-19}

DAVID HUNDT

$\mathbf{F}$ OR South Korea, which has handled the challenge of COVID-19 as well as if not better than most other countries, responding to the pandemic has been an opportunity to burnish its 'national brand'. It has experienced relatively few daily infections, cumulative deaths are not high by world standards and vaccination rates are above global averages. The 'tool-kit' of policy responses for managing the pandemic is theoretically the same for all countries, but the hallmark of South Korea's approach has been the ability to make pragmatic choices amid imperfect conditions.

The pandemic has witnessed the revival of some aspects of the 'developmental state' tradition in the sphere of public health. An approach to governance that had been associated with economic development gained new traction during the pandemic. At a time of great uncertainty about the causes of the virus and its effects on society, the public in South Korea and elsewhere have generally welcomed the prospect of confident and purposeful intervention from the government. South Korean leaders have adopted a reactive rather than passive or preventative approach that reflects the country's relatively small geographic size and its organisation as a unitary state under a powerful executive government.

From the outset, Korean leaders were careful to define success in terms of containment rather than elimination of the virus. The goal was always to minimise infections, hospitalisations and deaths, but there was an assumption that some infections were inevitable in a densely populated country, in part due to its proximity to the epicentre of the pandemic, in China. South Korea's experience in handling other pandemics in the early 21st century gave the government confidence that it could prevent the virus reaching critical levels of spread. An extensive contact-tracing regime developed during the Severe Acute Respiratory Syndrome (SARS) and Middle East Respiratory Syndrome (MERS) pandemics were brought to bear in the Korean approach.

South Korea adopted a relatively permissive stance on international borders. This reflects demand for migrant labour in the Korean economy, its close integration with China and the comparatively high levels of interaction between South Korea and China. The rapid and unexpected influx of the virus caught Korean officials by surprise and foreclosed the 'elimination' option, so it might have been tempting to shift the blame onto China. But the government correctly noted that South Koreans themselves, including members of the Shincheonji church in Daegu, were primarily responsible for bringing the virus into the country and its spread. The decision to avoid blaming China for the virus helped prevent an already fraught relationship with Beijing from getting worse.
South Korea's prior experience managing pandemics-and its willingness to keep its borders relatively open-gave it confidence that it could manage the challenge with light-touch measures such as contact tracing, home quarantine and masking. There were minimal economic shutdowns, and economic life proceeded significantly undisturbed with some adjustments. South Korea offered little in the way of allowances for laid-off workers and those who were forced to work from home. Public debt increased only modestly between 2020 and 2021. One indicator of the effectiveness of these measures in minimising disruptions to life as usual was the fact that the April 2020 legislative elections took place on schedule and with the highest turnout in 30 years.

\section{N KEEPING with the \\ developmental state's traditional} emphasis on industrialisation, Korean firms switched to producing masks and test-kits for both domestic use and for export. In May 2020, South Korea donated 2 million masks to the United States to relieve shortfalls during the first wave of the virus. Another 500,000 were given to the Department of Veterans Affairs, in a symbolic repayment to the US military for rescuing South Korea during the Korean War. A Korean test-kit was developed and distributed within weeks of the virus reaching Korea, thanks to close collaboration between 


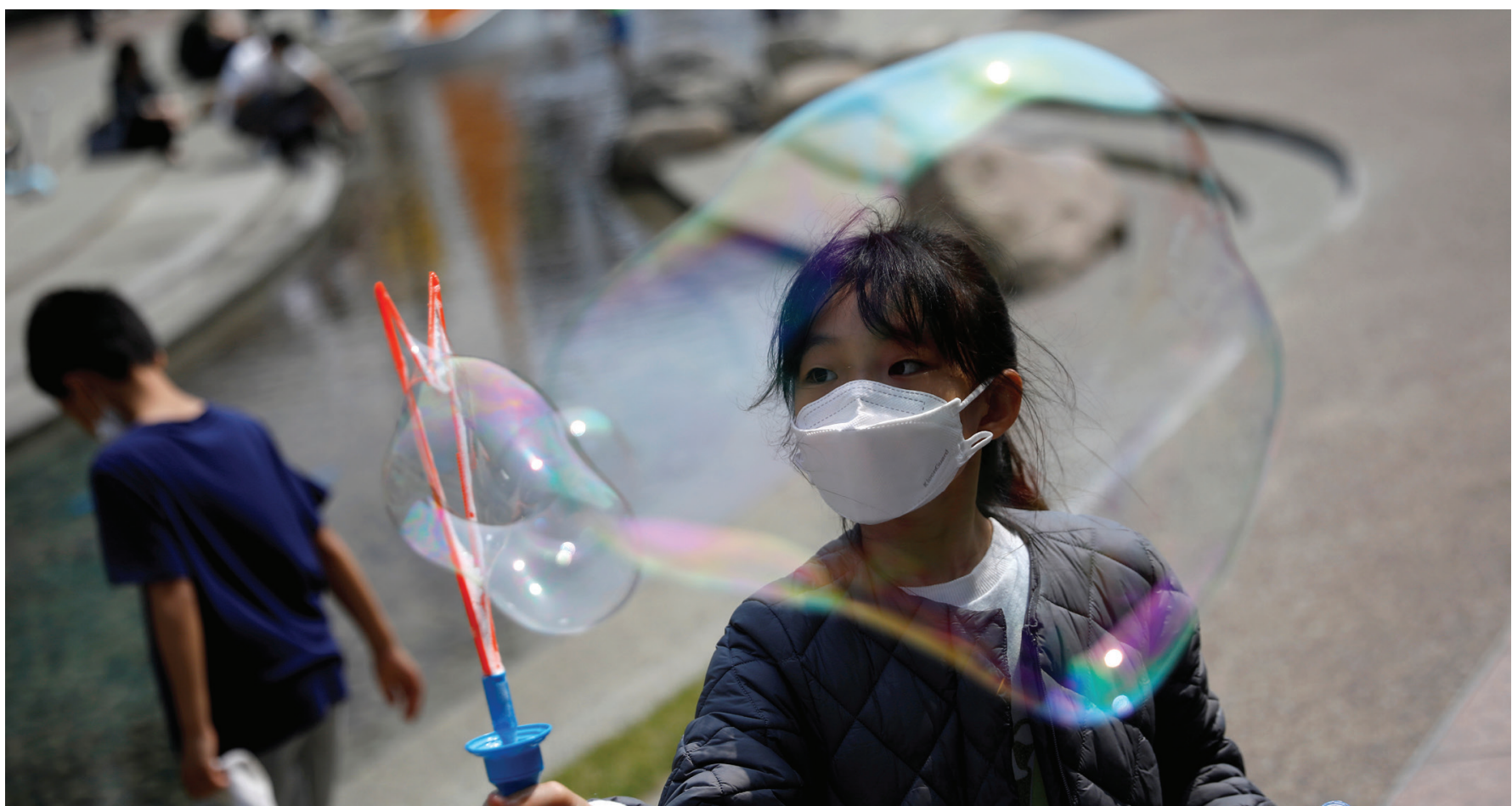

A young girl, wearing a protective mask to avoid the spread of COVID-19, plays with bubbles at a shopping mall (Gimpo, South Korea 2020).

the government and industry.

South Korea has packaged its pandemic diplomacy within the Moon Jae-in government's New Southern Policy, which aims to improve relations with ASEAN and India. The policy's three pillars-economic cooperation, sociocultural development, and peace building-address the 'high politics' of security and economics as well as the 'low politics' of people-to-people relations. South Korea has sought to address the strong demand for 'affordable and accessible' vaccines, as well as economic recovery, in densely populated developing countries such as Indonesia. Korean diplomatic overtures in core Southeast Asian countries, especially Singapore and Indonesia, have presented COVID-19 diplomacy to complement a longer-term goal of fostering interests in the region.

In many senses South Korea's pragmatic approach has fared favourably when seen alongside the more authoritarian version of developmentalism in China and the liberal approach of some Western states, some of whom have suffered high rates of deaths and infections. The Korean approach has been reasonably consistent and coherent thanks to a commitment by the government to communicate openly with the public and to follow the advice of health professionals. This has engendered a strong sense of national unity and purpose. People appreciated being allowed to go about their daily lives with a relatively high degree of normality.

But no single approach is a total panacea, and certainly not South Korea's. The country remains open to some international travellers, but formerly popular tourist areas such as Myeongdong have turned into 'ghost towns' due to their heavy reliance on foreign visitors and restrictions on the size of gatherings. There has been a decline in public approval of the government's slow vaccine rollout, and there is evidence that vaccination rates could be much higher now if the government had acted earlier. Foreign-passport holders have been subjected to arbitrary treatment in terms of testing, which casts doubt on the willingness of South Korea to edge away from the exclusionary forms of nationalism of previous eras.

Despite these shortcomings Moon has avoided the historical curse of South Korean presidents, who tend to suffer a chronic decline in popularity and effectiveness over their presidential terms. This suggests that the Korean public recognises the enduring benefits of the developmentalist model of pragmatic governance in spite of its downsides.

David Hundt is an Associate Professor at the School of Humanities and Social Sciences, Deakin University. 


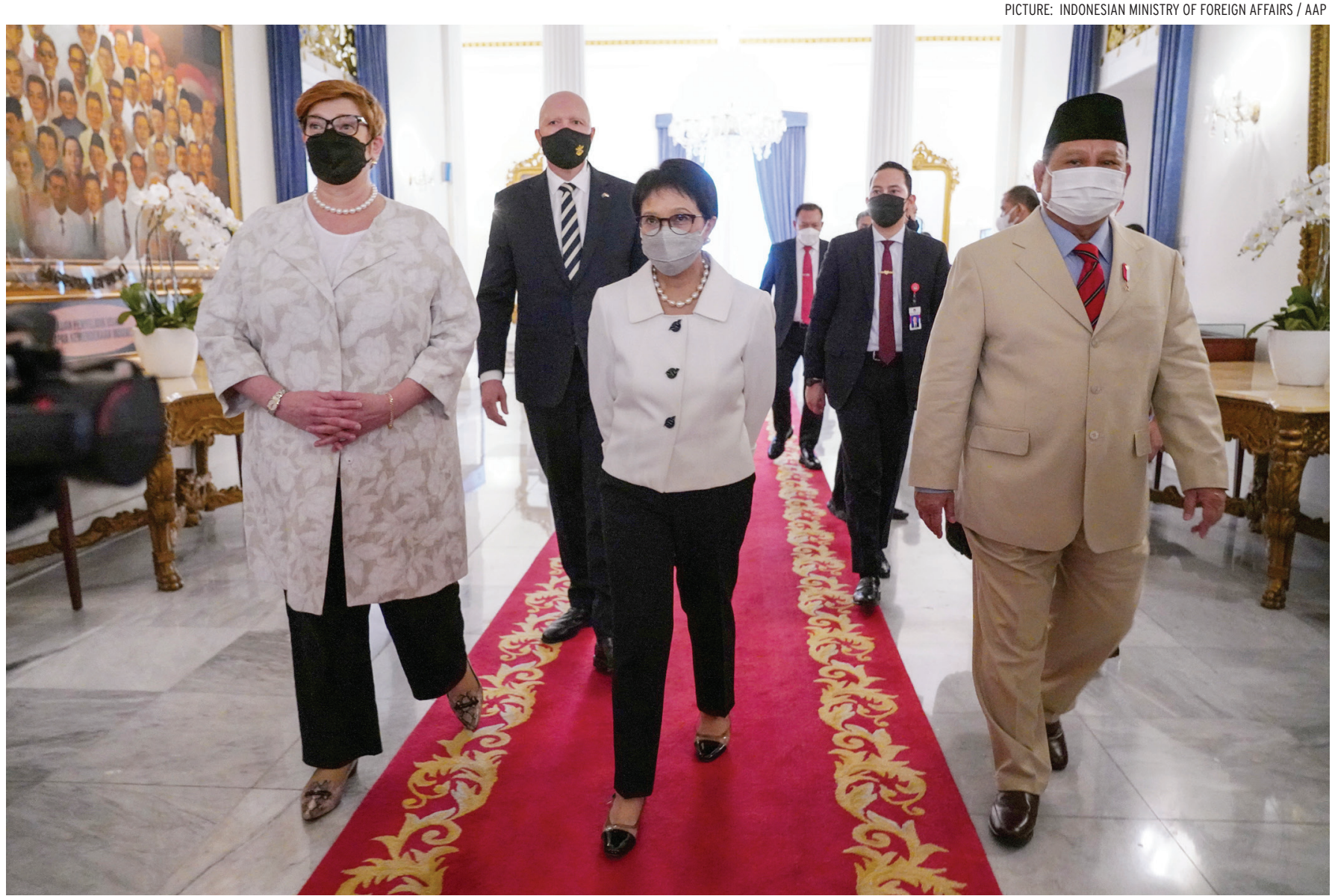

Australian Foreign Minister Marise Payne, left, and Defense Minister Peter Dutton, rear left, shown walking with their Indonesian counterparts Retno Marsudi, center, and Prabowo Subianto, right, during a meeting in Jakarta (9 September 2021).

\section{ASEAN responses to AUKUS security dynamic}

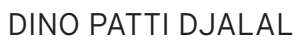

W

HEN news of the AUKUS agreement broke on 16 September 2021, it caught everyone in Southeast Asia by surprise. While it is understood that AUKUS is not an alliance, it had portent to agitate the strategic landscape for ASEAN.

In Indonesia, not a single member of parliament endorsed it. The government issued a five-point response which avoided any mention of AUKUS itself but stated that Indonesia 'was deeply concerned over the continuing arms race and power projection in the region. Jakarta was clearly wary of this development.

Malaysia shares similar concerns to those of Indonesia about whether the arrangement would precipitate a regional arms race. Malaysia is also worried that, although Australia is not set to acquire any nuclear weapons under the agreement, the transfer of nuclear technology to power Australian submarines might be the thin edge of the nuclear weapons wedge. This worry was echoed by 
ASEAN welcomes

open competition

between the big

powers within

the region, of the

right kind-namely

competition in peace

and for progress.

Indonesia's Director General for Asian, Pacific and African Affairs, Abdul Kadir Jailani, who wrote that Australia, the first Non-Proliferation Treaty country to build nuclear-powered submarines, 'may set a dangerous precedent' for others to follow. In that same article, however, Jailani points out that Australia's nuclear-powered submarine project does not violate the Southeast Asian Nuclear Weapons Free Zone.

In particular, AUKUS lifts the constraints on China from sharing its sophisticated military technologies. While China is unlikely to establish formal alliances, it may well be tempted to set up AUKUS-like defence arrangements with other countries in the region.

Across ASEAN (known for its consensus approach to diplomacy and policy decision-making) there is no consensus on AUKUS. Singapore's stance is somewhat neutral, hoping it will strengthen regional peace and security, and Vietnam and the Philippines see it as a welcome step towards a strategic balance in the regional geostrategic competition. Given this diversity of perspectives,
Indonesian Foreign Minister Retno Marsudi is unlikely to press the matter formally with her fellow ministers in the absence of further developments.

ASEAN is obviously not the target of the nuclear submarines nor other aspects of defence cooperation that are expected under AUKUS-it is well understood in the region that the submarines have China in their sights. Australia and the United States are also dialogue partners of ASEAN and their relationships thus far have been solid and stable. But where the agreement leaves ASEAN strategically and what impact it might have to ASEAN centrality as a balancing force in Asia's security equation is a deeper question. Some in Southeast Asia are worried that AUKUS could affect ASEAN's stabilising role in a volatile geopolitical landscape.

$\mathbf{T}$ HE diplomatic damage to Franco-Australian relations caused by AUKUS may also have some unintended consequences. France, which considers itself an Indo-Pacific power with a large footprint in the region, had put much store on Australia in its forwardleaning strategy in the regionindeed, French President Emmanuel Macron announced his Indo-Pacific strategy in Sydney in 2018. Given the present chill, France would now seem disinterested in any strategic cooperation with Australia. But France remains bullish on its IndoPacific strategy, and, if French Foreign Minister Jean-Yves Le Drian's recent visit to Indonesia is anything to go by-Indonesia was the only country in Asia he visited-Paris seems to be both exerting a stronger effort to embrace Indonesia over Australia in its Indo-Pacific strategy and placing greater weight on ASEAN.

Canberra has missed no opportunity to reassure Jakarta of Australia's support for ASEAN centrality. It is important, though, that Australia follows through on strengthening the practice and application of ASEAN centrality, which is at the heart of ASEAN's contribution to regional stability in Australia's backyard.

ASEAN may have impressive convening power and may well be in the driving seat of the region's diplomatic arrangements, but it also has serious work to do in the hardball game of managing geopolitical rivalry in the region. In its dealings with Beijing and Washington, ASEAN's diplomatic posture has been too soft and its voice too muted. ASEAN needs to articulate its interests more forcefully to maintain and shore up its relevance in the geostrategic chessboard of the region. That might well mean being somewhat less polite and a little more blunt.

ASEAN also needs a strategic design that is laid out to the competing powers and accepted by them. This is a difficult but not an impossible challenge for an organisation that relies on consensus and has ten member countries, some with their own alignments with the two major powers across a range of issues. The East Asia Summit, for example, has not yet evolved into a decisive forum wherein the major powers and ASEAN countries can enhance cooperation and reduce rivalries. Marty Natalegawa, former foreign minister of Indonesia, once proposed the idea of an 'Indo-Pacific treaty' that would be tantamount to applying the norms of ASEAN's Treaty Amity of Cooperation (TAC) to the wider IndoPacific region, but the idea has so far struggled to gain traction.

ASEAN welcomes open competition between the big powers 
within the region, of the right kind-namely competition in peace and for progress. ASEAN countries stand to benefit from positive competition among China, the United States and Japan, for example, for trade, investment, and educational opportunities. What ASEAN does not want is the kind of bitter zerosum rivalry that would create tension, mistrust, and division, thus (once again) pulling the region apart.

D ESPITE the initial furore over the AUKUS agreement, the controversy has died down. It has not, as some feared, seriously undermined strategic trust between Australia and its ASEAN partners. Indonesia, while certainly displeased not to have been forewarned-particularly given the $2+2$ meeting that had taken place between the two countries' foreign and defence ministers in early Septemberwas in no position to take Australia's secrecy surrounding the agreement personally given how France was kept in the dark.

Australia, the United Kingdom and the United States need to engage in serious confidence building in the region. In particular, it would be good for AUKUS countries to develop confidence building measures with China. Of course, this would require a significant elevation of diplomatic tradecraft, and political courage.

Demonisation of China, now one of few bipartisan issues in Washington, is all too fashionable. In an increasingly polarised world, greater effort to bridge the divide needs be made because it is crucial to Asia's economic and political security.

Here, there is an important role for middle powers such as Australia and groupings such as ASEAN to push for a strategic entente between the two major powers who, trying to resolve things alone, are likely to make less progress. EAFO

\section{Dr Dino Patti Djalal is Founder} and Chairman of the Foreign Policy Community of Indonesia, a former Indonesian Ambassador to the United States, a former Indonesian Presidential spokesperson and Deputy Foreign Minister of Indonesia.

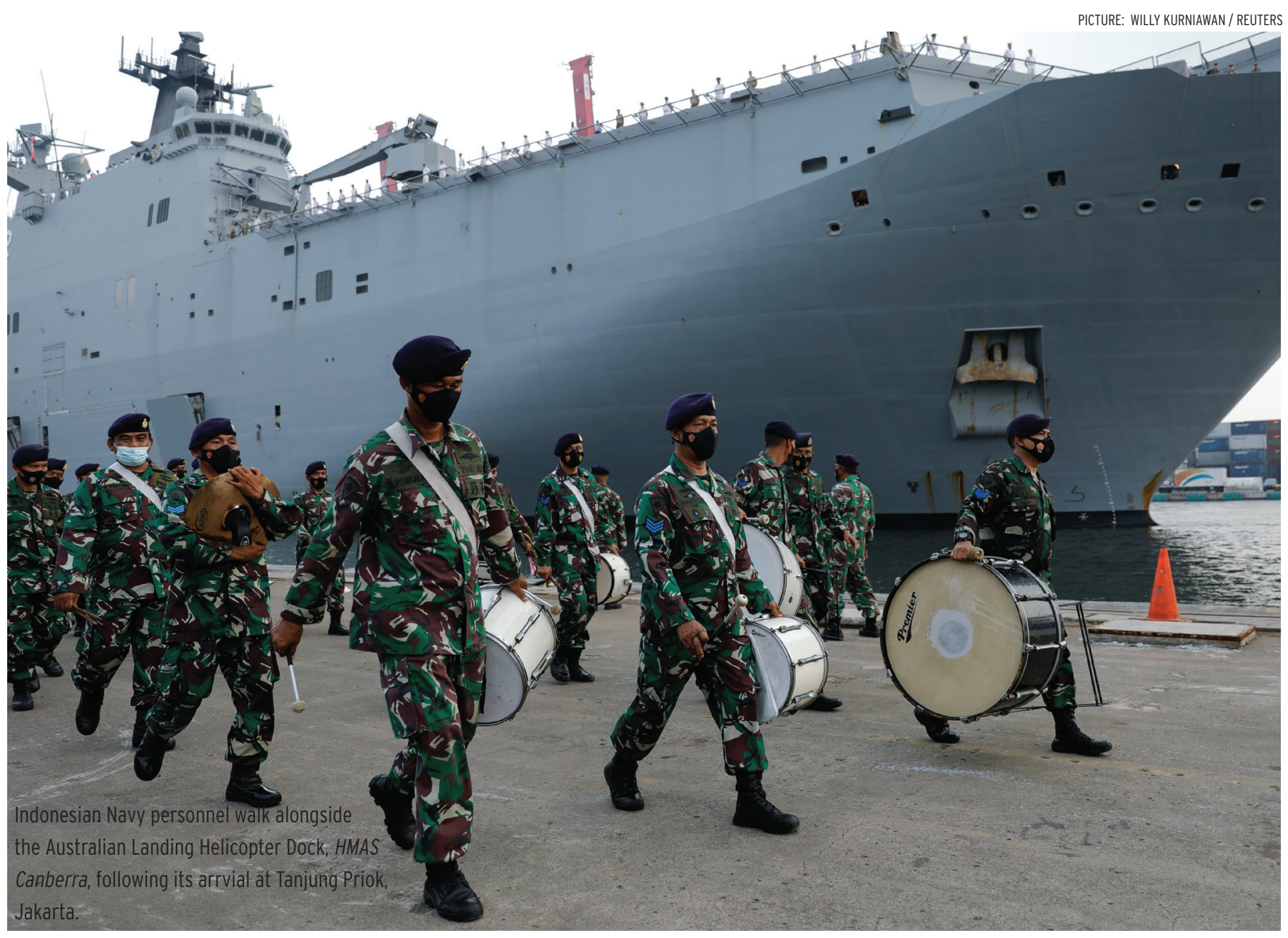




\section{Lonely hearts look for love in China's revolutionary dating landscape}

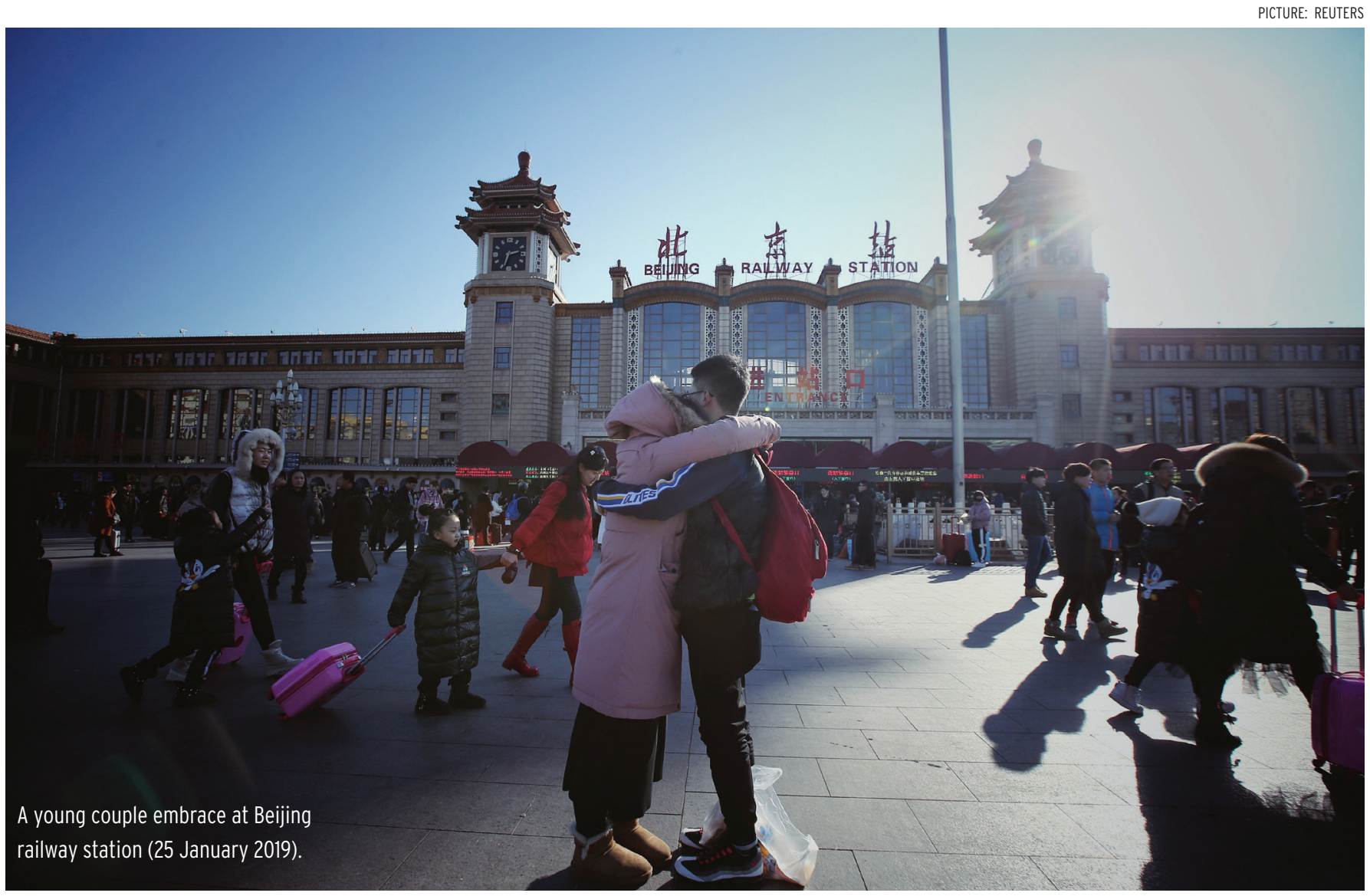

PAN WANG

- INCE the mid-2000s, China's

- street parks - originally imperial gardens or memorial sites for revolutionary martyrs - have become new tourist attractions and popular venues for marriage matchmaking. These 'marriage matchmaking corners' or xiangqinjiao can be seen in cities across China such as Beijing, Shanghai, Nanjing, Hangzhou and
Suzhou. They are organised by parent volunteers attempting to find a partner for their children. Initially, they were small gatherings formed by parents who went to the parks for morning exercise. They then grew into larger groups and became immensely popular nationwide.

Large parks such as Zhongshan Park in Beijing and the People's Park in Shanghai attract thousands of participants, with the majority of parents in their 50s and 60s. Many of the parents have been 'on duty' for over a decade, convinced that street park matchmaking is more reliable than other forms of dating (xiangqin) for their children as it provides opportunities to meet other parents and act as 'gatekeepers' to their 
children's selection.

Many of these parents grew up in the Maoist era (1949-1976) in which they hardly experienced romance or dating due to the political nature of the period. Although the 1950 Marriage Law allowed people to marry and divorce freely, this did not translate into freedom in love and romance. They were largely restricted and shaped by Maoist political ideology.

When class struggle dominated everyday life during the first land reform campaign in rural China in 1950, peasants were mobilised to condemn landlords and urge them to return stolen land. People were grouped into class categories based on land possession, labour relations and family origin. People with good class labels (poor and lower-middle class peasants) had ample opportunities to choose a partner and were reluctant to marry down into a lower political category. Those with bad class labels (landlords and rich peasants) had limited opportunity to choose a partner and needed to compromise to marry.

The class struggle under socialism continued when the Communist Party of China (CPC) launched its Cultural Revolution (1966-1976). During this period, dating and romance were perceived as 'bourgeois' and incompatible with China's socialist ethos. Many prioritised study and work over 'personal matters', perceiving the latter as a barrier to achieving the common goal of revolution. Formal rules were imposed in different educational institutions to prohibit people from talking about romance. Whoever violated these bans risked public criticism.

When the 'Up to the Mountain and Down to the Countryside Movement' started from the 1960s, 17 million urban youth were mobilised to the countryside to learn from the farmers and workers living there. While this gave them the freedom to indulge in love and sex in the absence of parental supervision, they were discouraged from dating and instructed to postpone their marriages and devote their time and youthful energy to the socialist revolution.

Love and romance gained space to grow provided it met China's revolutionary goals and remained a catalyst for socialist construction. The establishment of people's communes during the collectivisation period (late 1950s-1970s) allowed people to interact, court and form close relationships.

Recognising how the engagement of different sexes could increase productivity, the CPC mobilised writers, teachers and students to compose love songs to convey the

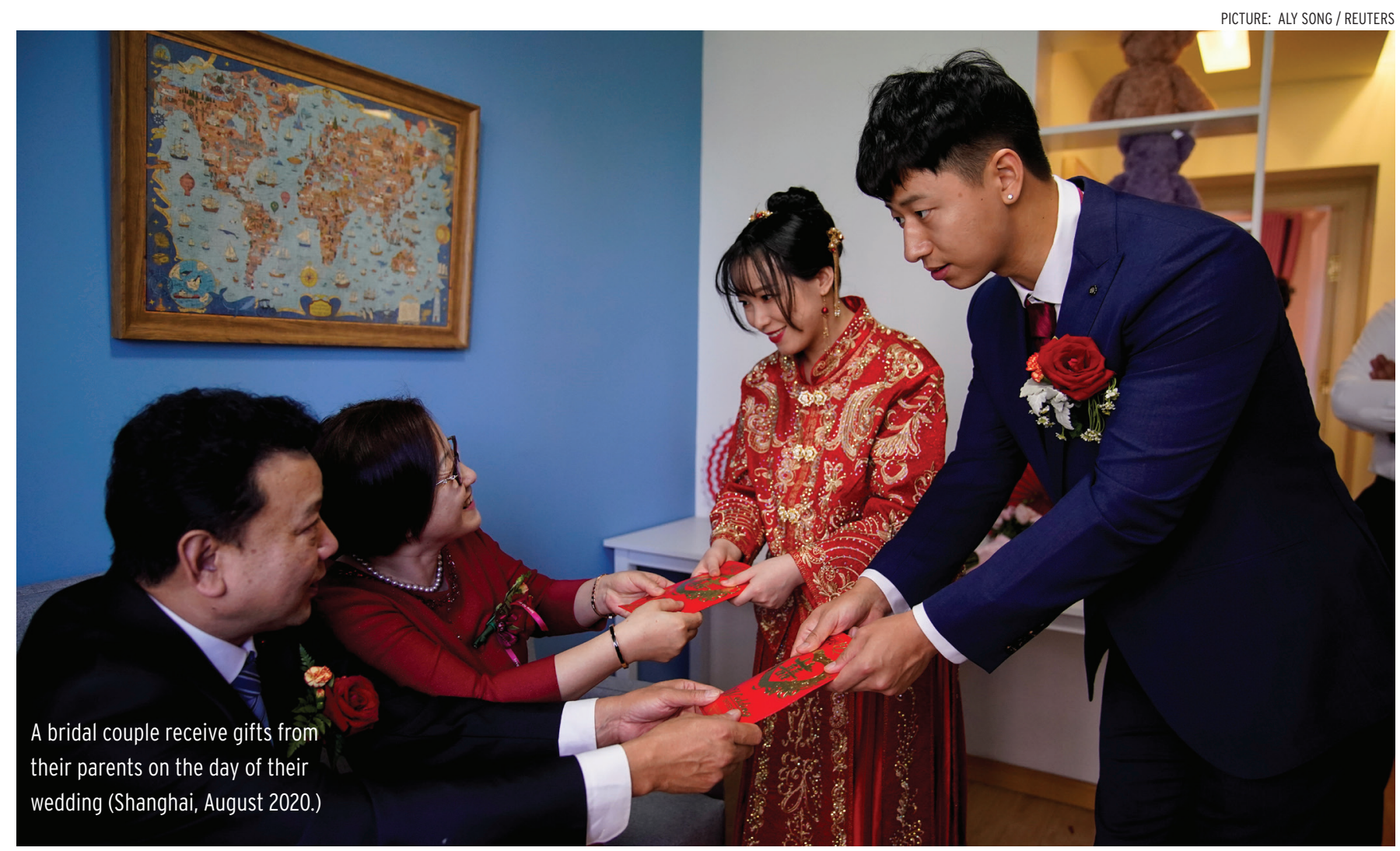


values and goals of collectivisation. Many songs combined courting with revolutionary goals and the 'right' political motives. During stressprovoking events like the Great Leap Forward (1958-1962), officials encouraged people to look for spouses, since undertaking arduous tasks and conquering difficulties together could help to build a solid foundation for marriage and cement social stability.

\section{N CONTRAST to their parents'} generation who grew up under the Mao era, most children of the parents attending matchmaking street parks were born in the opening up period of the 1980s and ' 90 s under the onechild policy. Family planning policycoupled with the engrained preference for sons-distorted China's sex ratio for years by producing millions of extra men of marriageable age. This imbalance has been exacerbated with more and more women choosing to pursue higher education or career advancement, delaying their marriage plans and 'squeezing' men and welleducated women in their late 20 s and 30 s out of the marriage market.

The rising cost of living and unaffordable housing of recent years has further discouraged people from seeking a partner or getting married. A growing number of men (mostly in the countryside) and women (mostly in urban China) are dubbed as 'leftovers', struggling to find a partner or not seeking one at all.

While parents are desperate to find partners for their children, media outlets have ventured into the dating and marriage matchmaking market. To help poor, rural men find wives, Shanxi Television launched China's first dating show titled Television Red Bride (Dianshi hongniang) in 1988. Unlike today's dating shows, Television Red Bride had no dating activities, no interaction, no entertaining games and no supporting friends or family. Contestants simply introduced themselves and nervously recited their prepared scripts in front of the camera. Despite its simplicity, the show moved topics of love, dating and marriage from the private realm to the public domain of broadcast TV for the first time in Chinese history.

With deepening economic reforms in the 1990s and early 2000s, China's media sector faced increasingly competitive pressures while dating shows proliferated. This accelerated the development of commercial entertainment shows with 'human interest' stories of love and romance. Over the past 20 years, dating shows such as Red Rose Date, One out of 100, If You are the One and Dating with the Parents have become enormously popular, winning the hearts of tens of millions of people. They have made watching others date on TV and gossiping about it a part of everyday life.

Controversial sayings such as Ma Nuo's remark 'I would rather cry in a BMW than smile on a bicycle' on If You are the One, television host Meng Fei's doctrine 'To give is to receive, to love is to be loved, and the Dating with the Parent's slogan 'Chinese-style blind dating: feel more secure with parents' have become collective dating memories of the new millennium. While these shows provided a platform for date-seekers to interact, flirt and talk about love, they also provoked the public to reflect on love, dating and marriage in China. And re-making love and dating on TV, has generated handsome revenues for Chinese producers.

From the mid-2000s, private agencies, dating websites and dating apps proliferated and developed their own business models. Privately
While parents are desperate to find partners for their children, media outlets have ventured into the dating and marriage matchmaking market

run dating camps and events target singles, teaching them how to date and attract the opposite sex, and create dating opportunities through social gatherings like cooking classes, hiking and afternoon tea.

Popular Chinese dating websites such as Baihe.com, Jiayuan.com and dating apps like Zhen'ai, MoMo and TanTan have hundreds of millions of registered users. These platforms launched online dating workshops and tutorials on dating tips and integrated diverse interactive activities such as music, group chatting, animated games, image galleries and live streaming. Gay dating digital networks such as Blued, Aloha and Grindr also grew popular to meet the needs of China's growing LGBTQI+ community. While many users have found love through these digital dating networks, others remain content with platonic-style romance in the virtual world.

China's economic reform has also boosted opportunities for international romance. From the 1980s, Chinese-foreign romance was no longer perceived as 'bourgeoise' as in the Cultural Revolution and dating foreigners gradually became normal. A rising number of Chinese 
the growing popularity

of Al dating and dating

simulation also reflects

the rising level of

Ioneliness in China and

the harsh reality of

those unable to find a

partner in real life

women have entered Chinese-foreign marriages, that is with men of foreign ethnicities and Chinese descent from outside mainland China. 'First-class Chinese women marrying overseas' was a popular saying in the $1980 \mathrm{~s}$ and 1990s that alluded to the growth of international romance and the superior status of women who married men from 'first-world' countries.

Foreign romances invited controversy against a backdrop of growing political sensitivity towards the West following the 1989 Tiananmen movement, the subsequent 'brain-drain' of Chinese nationals, and rising nationalism in support of China's political campaign against negative foreign influences like 'spiritual pollution' and 'bourgeois liberalisation. Critics equated Chinese women's 'upward' dating and marriage mobility with 'western fever' and 'western worshipping' and their foreign partners were dubbed as 'green cards' and 'flight tickets'.

Despite the controversy, Chineseforeign romance continued to grow. Statistics from the Chinese Ministry of Civil Affairs show that around 80,000 couples registered a Chinese-foreign marriage in 2001 compared to 8,460 couples in 1979. Entering the new millennium, China's record-breaking economic achievement and its rising international status reversed the migration patterns of Chinese-foreign couples. Many chose to take advantage of China's booming economic opportunities by living there.

$\mathbf{F}$ ROM the early 2010s, Chinese singles, primarily in their 20 s and 30s have started running their own dating businesses. This started with a small bunch of bachelors on social media seeking to 'hire' a girlfriend to bring home for Lunar New Year gatherings to reassure their families about their relationship status and future marital prospects. Within a few years, this grew into date-renting businesses such as Rent Friends Network (Zuyouwang), Rent Friend Group (Zuyou yizu) and Hire Me (Zuwoba).

On these platforms, users could either rent a date or rent themselves out. Some look for love, some intend to make money, some look for 'dateperformers' to placate their family, some want to make friends, and some simply seek serendipity. Common services include meeting friends, having dinner dates, watching films, playing games, travelling, or having a personal conversation. Prices, sometimes negotiable, vary from free to thousands of dollars.

Date-renting platforms profit from user blogs which provide a space to share love stories and dating experiences. Many users compile 'mood diaries' (xiangqin riji) documenting their feelings and thoughts on love, their personal experiences and details on their preferences, rules and prices to attract clients. User profiles, online diaries and data flows-collected via commenting, liking, and messagingprovide a wealth of 'affective data' which contributes to a platform's financial profitability.

The date-renting business has not eroded intimate social ties, but rather created new connections and social possibilities. Through these trading platforms, dating has become a privatised, contractual and tailored service among netizens. Love and dating are initiated through financial transactions and dating practice provides opportunities for love, friendship and other close relationships. Such commodified intimacy can be maintained as a durable economic relationship or converted to friendship, authentic romance, or other types of relationships.

On the positive side, date-renting has provided a solution to growing loneliness in China, especially for single men who are unable to find a date due to their disadvantaged status in the marriage market. But it raises concerns around authenticity, information security and personal safety, such as scams, deception, prostitution and fake marriage.

An interesting paradox of daterenting is that while it has attracted a rising number of singles to trade relationships, it has discouraged people seeking real dates or longterm relationships. This aligns with the paradoxical logic of the daterenting agencies-while supporting singles to find dates, agencies need to sustain their growth by retaining and attracting more singles. Daterenting will likely increase the number of singles and attract more people working as 'dating professionals'. Dating has become an object for consumption and a business for individuals and firms to capitalise on.

AI technology has provided 
another platform for lonely hearts to find love. In recent years, a growing number of Chinese people have started to date virtual robots. Xiaoice (Microsoft Little Ice) is a chatbot developed by Microsoft Asia Software Technology Centre (STCA) in 2014. The smart filter-powered by a sophisticated algorithm - and emotion-screening system has a broad knowledge of art, sports and world politics. It knows how to initiate a conversation, flirt, joke, provide emotional support and can be customised to become the ideal virtual partner via texts and voice and photo messages. So far the chatbot has reached over 660 million users globally. In China, Xiaoice has become a loyal date to millions of people, especially males from lower-income backgrounds.

The dating simulation game Love and Producer (Lian yu zhizuoren) developed by Suzhou's Papergames has similarly become a sensation for millions since its launch in 2017. Especially popular among young women, the mobile game made approximately RMB 20 million (AUD 4.1 million) on its peak day and has been downloaded more than 7 million times, with over 4 million daily active users. The game evolved from, and is similar to, the genre of otome games (literally 'maiden games') developed in Japan in 1994, which allow users to forge romantic relationships with five charming male anime characters through well-designed scenarios. These digital 'prince charmings' have won the hearts of many female game players. 'Fan-girlfriends' have spent as much as RMB 250,000 (AUD $52,245)$ to deliver birthday messages to one male character, Victor, via gigantic digital billboards in Kingkey Finance Tower in Shenzhen and, another, Gavin, via the Twin Towers in

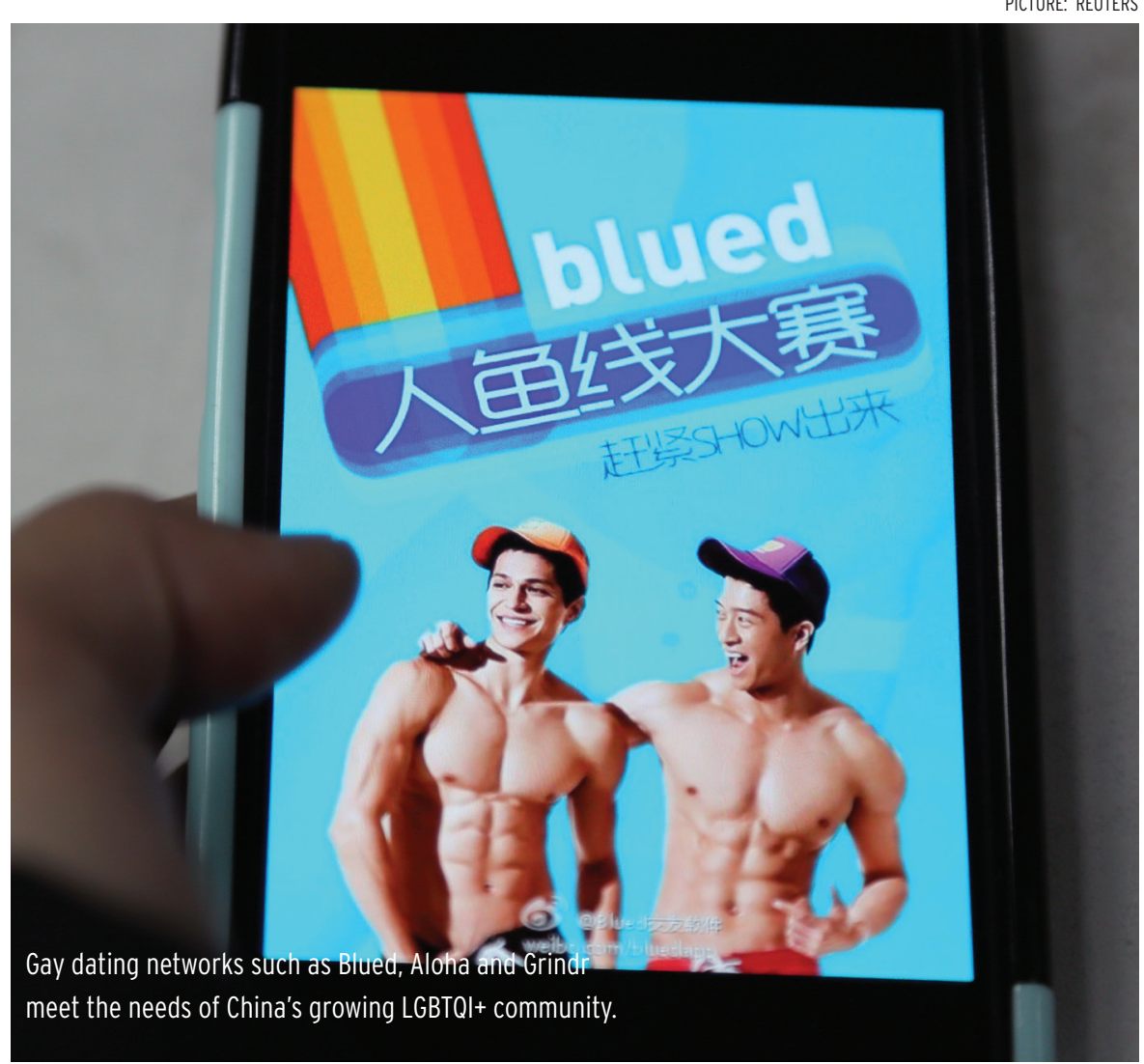

Shanghai.

The frenzy around dating simulation reflects the heavy influence of 'flowery men' culture-popularised by 'soft masculinity' or 'metrosexual' males - and fan culture modelled on J-pop and K-pop. It also indicates the growing desire of young Chinese women to consume content with fashionable masculinity, and their rising economic power driven by booming consumerism and feminism.

While a number of people date for entertainment or digital experimentation, the growing popularity of AI dating and dating simulation also reflects the rising level of loneliness in China and the harsh reality of those unable to find a partner in real life. As dating is no longer exclusively person-to-person, it will likely exacerbate China's already weakened dating-marriage link. As AI couples cannot achieve the goal of carrying on the family line it is certainly unlikely to contribute to the Chinese government's goal of elevating birth rates. Rather, it will likely enhance marriage delay and slow down marriage and birth rates in the long term.

Many Chinese parents uphold the conventional notion that 'marriage is the end goal of dating' and desperately seek a potential son or daughter-inlaw at street park marriage corners, but their children may be elsewhere. Perhaps they are waiting for an arranged date, are in a date-renting contract, falling in love with a digital boyfriend or girlfriend, or plan to 'forever-date' without entering into a marriage at all. EAFQ

\section{Dr Pan Wang is a Senior Lecturer in Chinese and Asian Studies at the} University of New South Wales, Sydney. 




A gay couple raises their hands as they march on a street during Korea Queer Festival 2015 in central Seoul (June 2015).

\section{The queer way of South Korea}

TIMOTHY GITZEN

\section{S INCE 2015, the annual Seoul Queer Culture Festival held at Seoul City Hall Plaza has grown steadily. The event hosts booths, performances and a parade through downtown Seoul, attracting tens of thousands of participants. The wide media coverage of these ostensibly progressive events sits against a still discriminatory and homophobic South Korean social, political, economic}

and cultural landscape, particularly influenced by the Christian right.

While there is no antihomosexuality or anti-sodomy law in the Korean civil code, there is an anti-sodomy law in Korea's military penal code. Given that all able-bodied Korean men are required to serve for at least 18 months in the military, activists claim that the law is a de facto national anti-homosexuality law. The battle for an anti-discrimination law and marriage equality rages on, while discrimination against transgender soldiers is slowly gaining public recognition. The latter is surprising given that changing one's legal gender is an almost insurmountable feat in South Korea.

People living with HIV/AIDS are routinely discriminated against and denied medical treatment. Often 
this occurs because sex education is withheld from students, making the discussion of sex at local hospitals and medical centres a problem for patients that need assistance. Queer people take to hiding themselves; they rarely 'come out' and instead seek strategies to live as part of society while finding ways to still be queer.

In this landscape the record numbers of queer culture festival participants is a significant statement, but there are lesser-known gains by the LGBTQ community that deserve greater international attention. The last 10 years have seen queer culture festivals emerge in locations throughout South Korea, including in Daegu, Busan, Jeju Island, Jeonju, Gwangju and Gyeongnam. There has also been a push to hold queer events in smaller regional towns outside of larger cities. The second annual Gwangju Queer Culture Festival in 2019 , for instance, attracted a large turnout and the festival has become a well-oiled machine in its two short years. This contrasts with Incheon's first Queer Culture Festival, held in 2018, which was derailed by the intense backlash and violence from anti-LGBT protesters

Home to the pro-democracy 1980 uprising that saw thousands of Korean citizens massacred at the hands of the authoritarian-led military, Gwangju is a symbol of Korean democracy. The importance of holding a festival advocating for LGBTQ rights here ought not to be ignored. It is also salient given the history of anti-homosexuality in the postwar authoritarian period (1960-1987), where cross-dressing at the time, for example, was a method of challenging authoritarian leader Park Chung Hee's conservative gender system.

The growth in LGBTQ organisations, groups, publications and spaces has been huge. In 2019, there were 27 activist organisations, eight networks, 16 media outlets or organisations, seven research groups and two mentoring or crisis centres. There is substantial growth in LGBTQ university organisations, with over 70 organisations registered in 2019. The first university group, Come Together, was formed in 1995 at Yonsei University and for many years, only the top three universities had an LGBTQ organisation. This signals a broader shift in LGBTQ politics which lies in the hands of the younger generation.

W HILE these festivals and university organisations create transformative spaces that are important and offer moments of celebration and acceptance, they may not do much to change things. One that is making a difference is the organisation Söngsosuja pumomoim, or PFLAG (Parents, Family and Friends of Lesbians and Gays) Korea, which works to break down social walls by addressing one of South Korean society's most fundamental social units: the family. The organisation began in 2014 as an incubation program with a local Korean activist organisation.

Given the importance of traditional, heteronormative families in South Korean society-a fraught landscape that LGBTQ folks must expertly navigate-the importance of the work that parents do to advocate for their LGBTQ children and LGBTQ rights more broadly cannot be understated. PFLAG Korea is a space for parents and children to congregate, share their stories of coming out-including parents' stories of accepting their LGBTQ children - and seek validation from each other. It is also geared towards educating Korean society queer activists are cautiously optimistic that legal gains are on the horizon, especially an anti-discrimination law

about the importance of LGBTQ rights and acceptance. In 2015, PFLAG released the book Nanŭn sŏngsosujaŭ $i$ pumonimida (I am a Sexual Minority's Parent), featuring background information about the group, interviews with various parents, articles written by parents about their experiences and transcripts of their first 17 monthly meetings.

There have been significant material gains within the LGBTQ community and in broader Korean society on LGBTQ rights. I have noticed in my research that queer activists are cautiously optimistic that legal gains are on the horizon, especially an anti-discrimination law. They also recognise the importance of groups like PFLAG Korea that have shaped social and cultural changes, particularly around issues like the centralisation of the family and the power of the parents of LGBTQ children to advocate on behalf of their children. It is these social and cultural shifts that are likely to elicit lasting changes for LGBTQ people in South Korea. EAFO

Timothy Gitzen is an anthropologist and Postdoctoral Fellow in the Society of Fellows in the Humanities at the University of Hong Kong. 


\section{CRISIS TO CRISIS}

\section{Escaping the North under Kim Jong-un}

JAY SONG

A S OF September 2021, data from the South Korean Ministry of Unification suggest that 33,800 North Korean defectors currently live in South Korea. This number has soared over the past two decades-before 1998, they numbered under 200. Following the collapse of the Soviet bloc and the devastating famine in North Korea in the mid-1990s, the turn of the century saw an influx of North Korean arrivals into South Korea rise each year, reaching its peak in 2009 at 2914. Since Kim Jong-un took power in 2012, the flow has largely stagnated and decreased and with COVID-19 has reached an alltime low.

Following Kim's succession, annual arrivals have not exceeded 1600. In 2020, with increased border restrictions due to COVID-19, only 229 entrants were recorded. A number

For ordinary North

Koreans life proceeds

from crisis to crisis,

rooted in patterns

that stem back to the

Korean War of factors explain this. The first is strengthened border control between North Korea and China. In the 1990s and 2000s, there were few barbed wire barricades across the exit route of choice, the Tuman river separating both countries. But under Kim's regime, both China and North Korea have heightened border security with more fences and checkpoints.

Increased social surveillance practices in China have also amplified the challenges facing defectors once they enter. In 2012, with China amending border laws affecting North Korean defectors, efforts to locate them have increased. Without official identification, it is extremely difficult to move around China without attracting suspicion. The adoption of AI-driven face recognition CCTV systems and other systems of social control have further restricted the mobility of defectors hoping to avoid detection. If they are caught and repatriated, there are detrimental consequences, individually and for their families.

Gender disparity across the North Korean migrants in South Korea is another clear dimension. From 2002, women have comprised 75 to 85 per cent of defectors in South Korea. This is a product of social norms in North Korean society. While all men in North Korea must complete at least 10 years of military service, women with middle or high school education are enlisted only between the ages of 17 and 22. Women are relatively more mobile and are more commonly involved in entrepreneurial and informal trading activities across the Chinese border. This likewise exposes women and children to increased risks of human trafficking, and many were sold as wives or cheap domestic labour during the famine and post-famine periods.

Changes in South Korean entry requirements for verifying the identity of self-claimed North Korean refugees is another challenge. These changes are attributed to fears of North Korean espionage, and the propensity of Korean-Chinese to enter South Korea falsely claiming defector status to receive government subsidies and more favourable work and residence rights than other foreign migrants. The South Korean government also changed the scale and nature of various subsidy schemes for North Korean defectors. Instead of outright cash payments, it now provides incentives that are tied to education, training and employment for longterm settlement and capacity building.

Fees for brokering services to cross borders via land, sea or air have also increased dramatically. In the 2000s, fees per person were around US\$34000. Now they have skyrocketed to US $\$ 20,000$. The air route has become largely inaccessible as faking Chinese passports is almost impossible. This has significantly restricted the number of individuals who can afford to leave. 
D ESPITE the barriers, North Koreans still have significant motivation for defecting. According to the 2020 Hana Foundation survey, the biggest driver for leaving North Korea was the food shortage, followed by political repression, a better environment for families, family reunion, economic opportunities, secondary family migration, personal security and recommendation from others. Family-related motivations have become a dominant pull factor for North Korean migration to South Korea under Kim.

Life satisfaction levels among North Korean migrants in South Korea are moderately high. Male defectors identify South Korea's competitive society as a main source of unhappiness, while women attribute life dissatisfaction to family separation. One in five North Koreans have experienced discrimination in South Korea. Teenagers commonly point to their low-income status, while older North Koreans attribute this to incompatible skillsets compared to their South Korean peers.

Some North Koreans prefer to undertake onward migration to Western countries. According to the United Nations Office of the High Commissioner for Refugees, the top destination countries for North Korean asylum applications in the past 10 years were Canada, the United Kingdom, Belgium, Russia and the Netherlands. Despite their strong human rights campaigns against North Korea, the United States has not accepted many North Korean refugees.

Migration in contexts like these elsewhere around the world is characterised by natural selection for survival. North Koreans are not unique in this respect. Humans have always tried to move to new locations where more freedom, safety and a

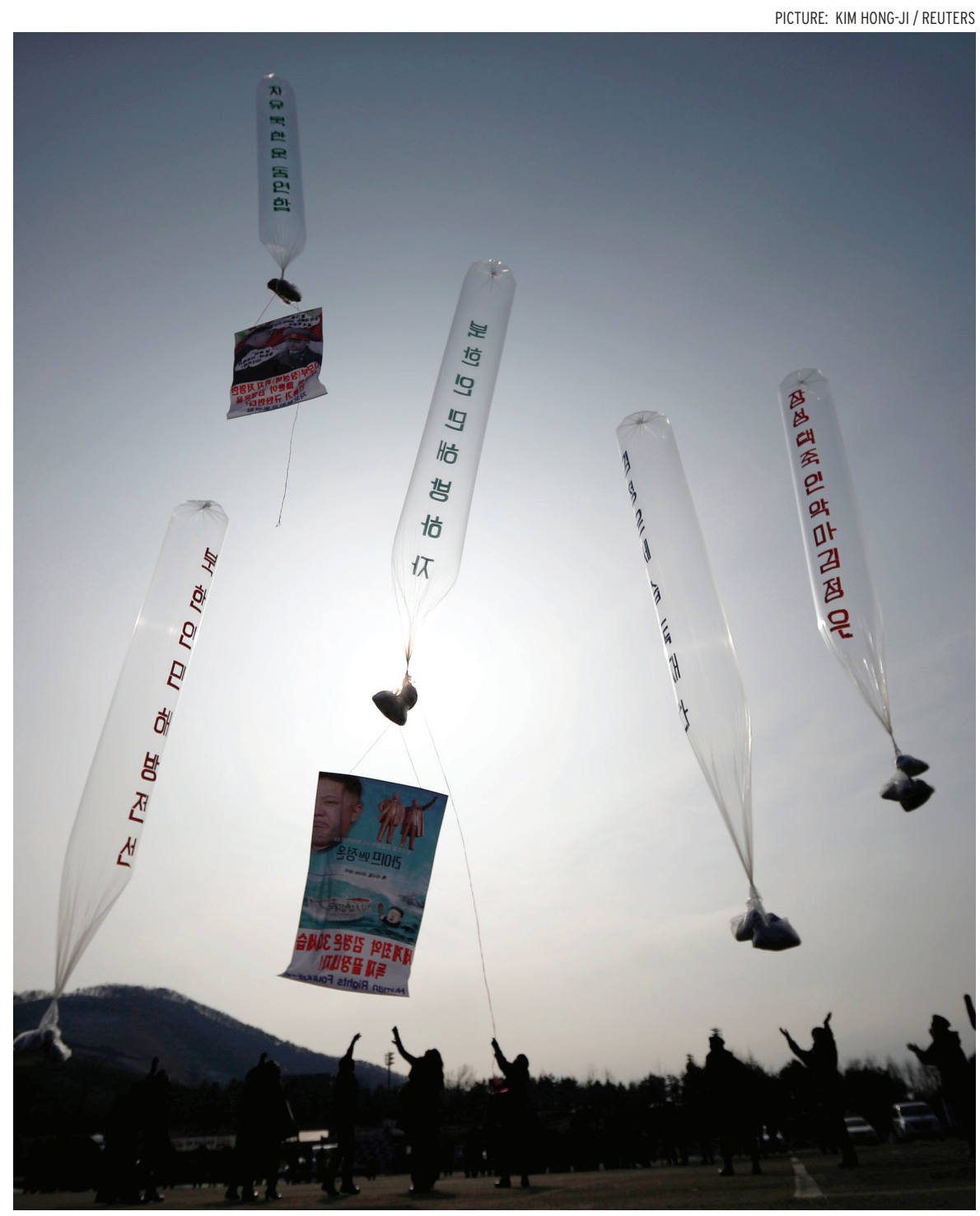

Former North Korean defectors release balloons with one dollar banknotes, radios and leaflets denouncing the North Korean regime north near the demilitarized zone separating the two Koreas (Paju, 2014).

higher quality of life are available. Families and social networks play key roles in facilitating the choice for mobility. States have likewise always sought to control people's inbound and outbound movements, especially in times of crisis.

For ordinary North Koreans life proceeds from crisis to crisis, rooted in patterns that stem back to the Korean War. As North Korea tightens border restrictions to prioritise regime survival-a strategy compounded by pervasive restrictions in neighbouring countries due to COVID-19-most of its citizens simply seeking to survive will continue to face an uphill battle.

EAFO

\section{Jay Song is Korea Foundation Senior}

Lecturer in Korean Studies at the Asia Institute in the University of Melbourne. 


\section{FILLING THE GAPS}

\section{Middle power conundrum amid US-China rivalry}

SHIN-WHA LEE

$\mathbf{T}$ HE INTERNATIONAL community has faced an unprecedented social and economic shock due to three 'big bangs'increasing US-China strategic competition, the fourth industrial revolution and the COVID-19 crisis. These three big bangs are interrelated and pose important challenges and consequences for world trade, regional stability and the future of the liberal international order.

First, the US-China trade conflict and strategic competition that began in earnest in 2018 stemmed both from a sense of crisis within the United States about China's unfair trade and

\section{In the international}

realm, middle powers

protect the interests

of small and medium-

sized countries,

providing a third ground

in which to weather the

storm of great power

competition industrial espionage and from the rapid economic growth, advanced technological development, and strengthening military power achieved through them.

Faced with an increasingly vulnerable global supply chain stemming from COVID-19, countries rushed to reorganise their supply chains to strengthen security. As the link between technology and security became more important, the US enacted a 'Special Act on Semiconductors' and hastened the 'internalisation' of the semiconductor industry. The reorganisation of China-centred global value chains is restructuring the world economy and trade. The United States and other developed countries are abandoning offshoring to China to cut costs and instead are reshoring, nearshoring or ally-shoring them. The trend of shifting value chains away from China is based on the judgement that leadership in advanced technology is the only means to maintain strategic hegemony.

Second, the pandemic confirmed that the postwar world order is unravelling. Although the global organisations and norms that have led international affairs and the economic order for the past 75 years are still in place their practical role and binding force are waning. It is unlikely that new organisations and norms will emerge to fill the gap, and the great powers show no sign of global leadership.

Instead of cooperating to combat the pandemic, the United States and China aggravated mutual distrust and antagonism. The relative decline of the United States and growing international distrust of Chinese leadership has created a 'G-Zero' era, in which the existing global governance centred on major powers has reached its limits and there is increasing instability and uncertainty.

Third, while the United States and China both advocate multilateralism; the two nations have different strategic goals, methods and approaches to its implementation. In their strategic competition, they are each mobilising multilateralism as a tool for mutual exclusion.

US President Joe Biden has criticised Donald Trump's 'America First' policy and declared alliances and multilateral cooperation as his top foreign policy priority. But at the heart of Biden's multilateralism, much like Trump's, lies the separation and containment of China. This reflects how the United States cannot cope with the rise of China by itself. Beijing criticises Washington's multilateral approach as 'closed and exclusive' and seeks to empower anti-Quad solidarity by strengthening traditional North Korea-China-Russia relations. Along with Iran, Beijing aims to construct a 'coalition of sanctioned states'. 
$\mathbf{T}$ HE accelerating US-China confrontation is forcing middle powers to re-evaluate their strategic positioning. In the international realm, middle powers protect the interests of small and medium-sized countries, providing a third ground in which to weather the storm of great power competition. Should a middle power choose either side, it risks retaliation or exclusion from the other-the limits of the strategic base and capabilities of middle powers are now clear.

Cooperation among democratic middle powers is important, because they share norms, values and rule of law to set economic and technological standards that help counter China's unfair and predatory behaviour. However, in relations with China, there are 'temperature differences' among many of the United States' middle power allies. What if they are 'like-minded,' but not quite 'likesituated, when considering their respective national interests and priorities?

Australia, for example, cites its close relationship with United States and Europe as an important reason to move towards greater solidarity with the United States. That middle power seems determined to defend its values and norms and abandon China despite strong trade retaliations. How then to explain Germany and France, equally traditional democratic allies of the United States, and their ambivalence towards the two great powers? They are deeply connected to China through trade and technology and also seem hesitant to fully invest themselves in technology coalitions such as the US-led democratic alliance and Clean Network.

South Korea is in an even more difficult position to make the binary choice between the United States and China. Unlike Australia-which is rich in natural resources and has the advantage of geopolitical distanceSouth Korea faces a strategic dilemma wherein to align with the United States for security and with China for the economy, risks its being abandoned by both.

There are doubts as to whether South Korea's diplomatic and strategic concerns about China's expanding influence can be resolved simply

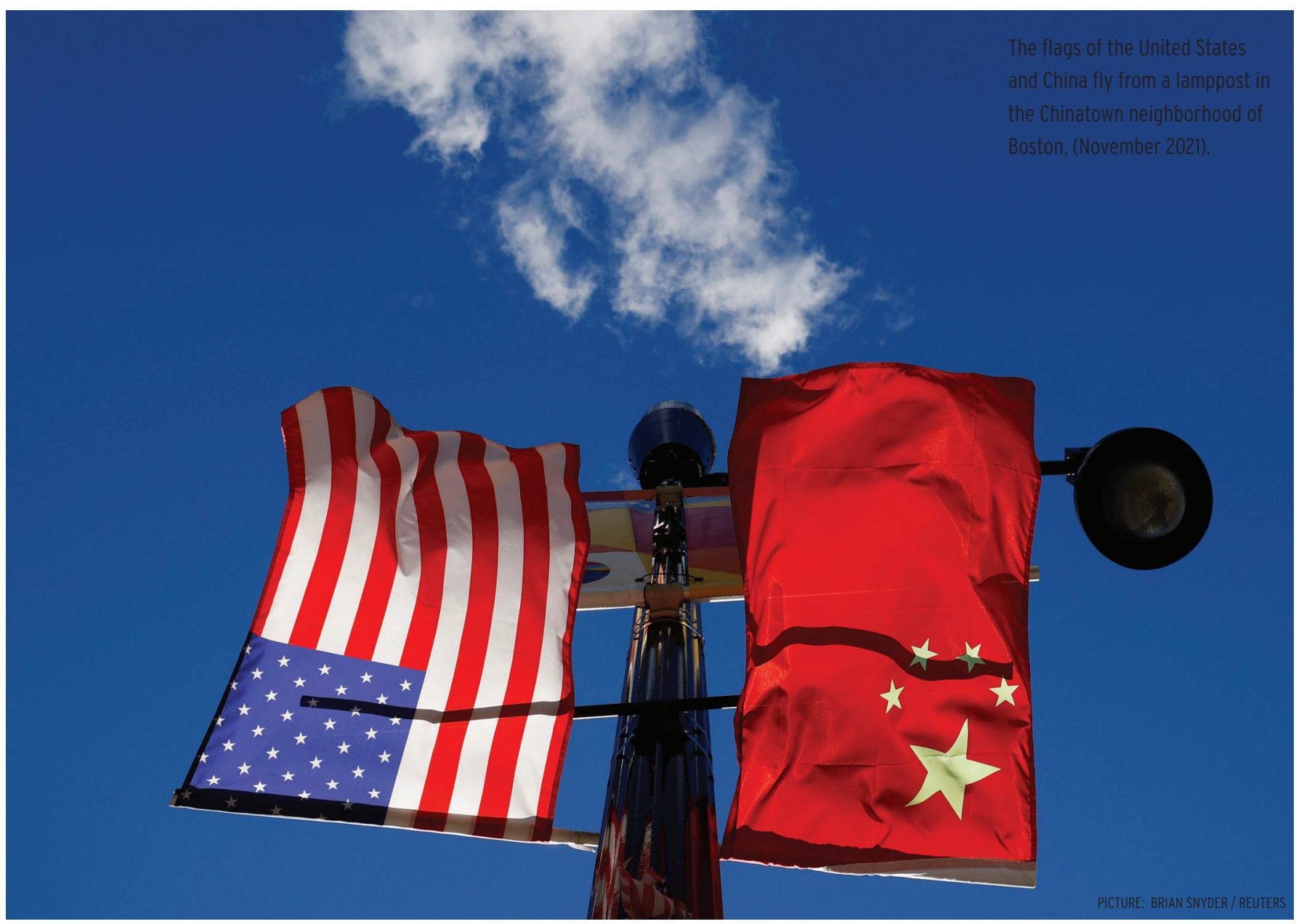


if a coalition of middle

\section{powers can fill the gaps}

in the multilateral system

and serve as a bridge

connecting US and

Chinese economic or

security interests, both

powers will recognise its

utility

through participation in democratic alliances. Yet cooperation with likeminded countries, notwithstanding China's growing strength, increases the likelihood of upholding liberal values and norms on trade and technology, and ultimately serves the national interest. The United States therefore needs to understand the unique positions of Korea and other middle powers facing the dilemma of this choice, and devise measures to compensate for the damage it may inflict.

Middle powers may often have felt dissatisfied with the framework of the postwar US-led liberal international order. At the same time, their participation in this order allowed them to maintain security and pursue a market economy, democracy and multilateralism. Their preferences lie in improving and renewing, rather than eliminating or replacing the status quo. Given the United States' technological capabilities, many countries are also likely to continue to be dependent on US semiconductors, software, and other advanced technologies for some time yet.

The international community is doubtful about the sincerity of China's multilateral initiatives. Beijing's predatory behaviour in the South and East China seas, trade retaliation against South Korea and Australia, and human rights issues in Hong Kong and Xinjiang are among the reasons for this scepticism.

Middle powers can assume a leading role in resolving problems that are important to the international community such as vaccine research, climate change and maintenance of open trade. They can also have some opportunity to exert influence over the great powers through numerical superiority and a united voice.

A coalition of middle powers may not exert enough influence to challenge the dynamic of great power politics. But, if a coalition of middle powers can fill the gaps in the multilateral system and serve as a bridge connecting US and Chinese economic or security interests, both powers will recognise its utility and give it standing.

The future of the liberal international order no longer depends only on the ability and willingness of the United States to continue providing global public goods but also the ability of the middle powers to ensure the order's maintenance and development. EAFO

Shin-wha Lee is a Professor of the Department of Political Science and International Relations, Korea University and President of Korea Academic Council on the UN System (KACUNS).

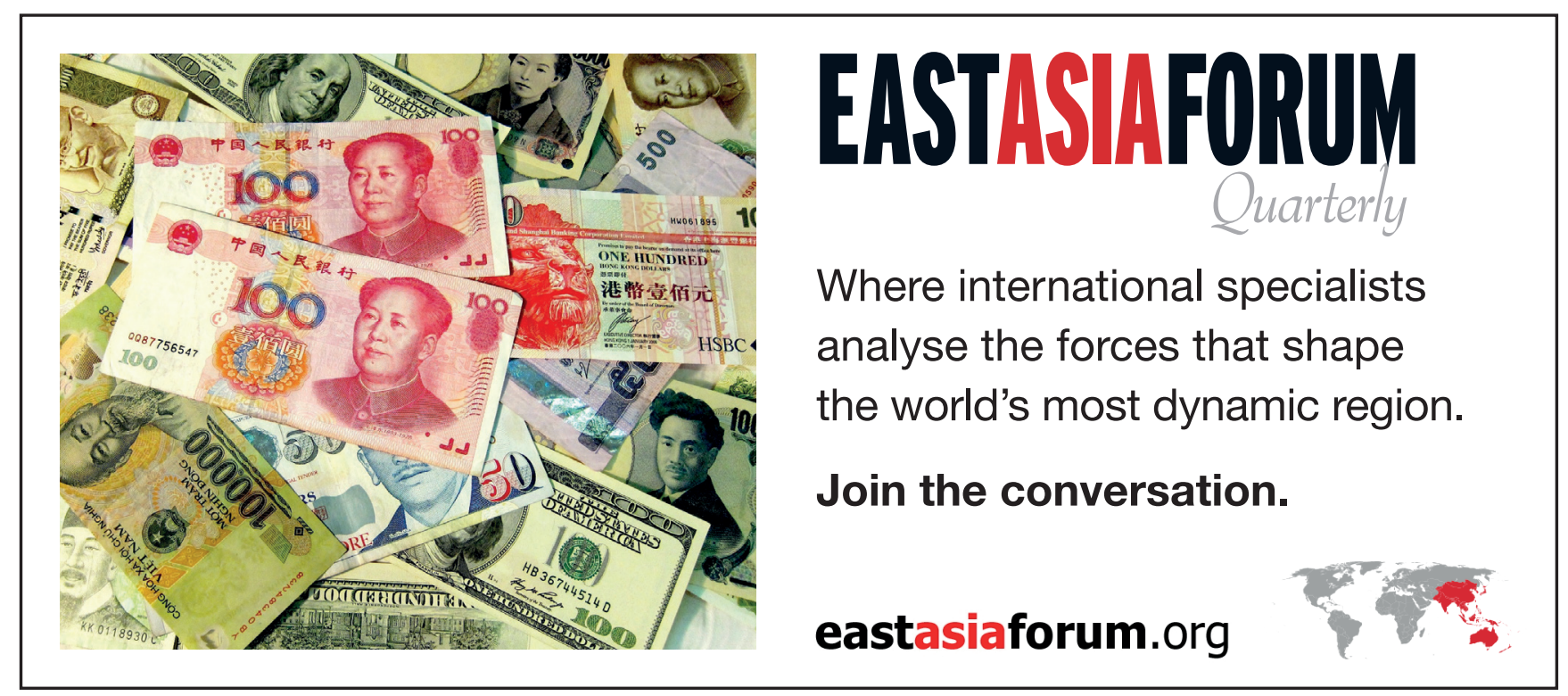




\section{MILITARY IN THE SPOTLIGHT}

\section{Putting South Korea's proactive national defence strategy in perspective}

BO RAM KWON

S

OUTH KOREA is under the

spotlight for unusual reasons.

On 15 September 2021, North Korea

tested a new long-range cruise missile and a submarine-launched ballistic missile. South Korea immediately tested its own capabilities including a ballistic missile, a supersonic anti-ship cruise missile, a long-range air-tosurface missile, a solid-fuel engine for space rockets and then fired its own submarine-launched ballistic missile. These competing military displays have raised questions about the strategic objectives of South Korea's build-up of technology-intensive national defence capabilities.

South Korea's defence budget shows its determination to build a more advanced and autonomous military force. The Ministry of National Defense's Mid-Term Defense Plan for 2022-26 allocated 315.2 trillion won (US\$271.5 billion) to defence-a 5 per cent increase over the previous five-year plan. The plan anticipates an average annual budget increase of 5.8 per cent: 106.7 trillion won (US\$90 billion) will go towards Force Improvement Programs that will incorporate cutting-edge technology in the military.

South Korea's evolving threat perceptions, ongoing defence reform and global aspirations as a US ally and middle power inform its renewed focus on defence.

The security environment in Northeast Asia has become increasingly unstable. North Korea's advance in nuclear and missile technology and its resolve to deploy tactical nuclear weapons poses an existential threat to Seoul. China's regional and global hegemonic ambitions have led to rapid growth in its strategic capabilities, increasing the likelihood and impact of intervention should a contingency on the Korean peninsula occur.

US alliances are being harnessed to align efforts to balance against China as the United States readjusts its global leadership role and seeks retrenchment. As competition between the United States and China intensifies, the North Korea nuclear issue risks being reduced to a peripheral problem or one to be 'managed' rather than solved. Together, these threat factors incentivise South Korea to pursue a multi-pronged national defence strategy that aims to strengthen deterrence against North Korea and China in the immediate and longer term.

South Korea has pursued Defense Reform 2.0 since 2018 to modernise its forces in response to demographic shifts that will reduce standing troop levels. The Mid-Term Defense Plan aims to conclude these reforms successfully. The main driver for reform is the notion that hightechnology advancements lead to new military capabilities tailored to an increasingly uncertain future, and that the military should expand its traditional frontiers to include cyber and space domains. Plans aim to incorporate emerging technologies developed by South Korean firms in ground-based missile defence, fighter aircraft and light aircraft carrier development. The directive is that South Korea should become less reliant on foreign defence sources while it grows independent conventional capabilities to respond to the North Korean nuclear threat.

Setting aside normative and practical reasons not to develop

South Korea's proactive defence drive is a

testament to heightened security anxiety [and] a resolve to deter nuclear and other complex threats 


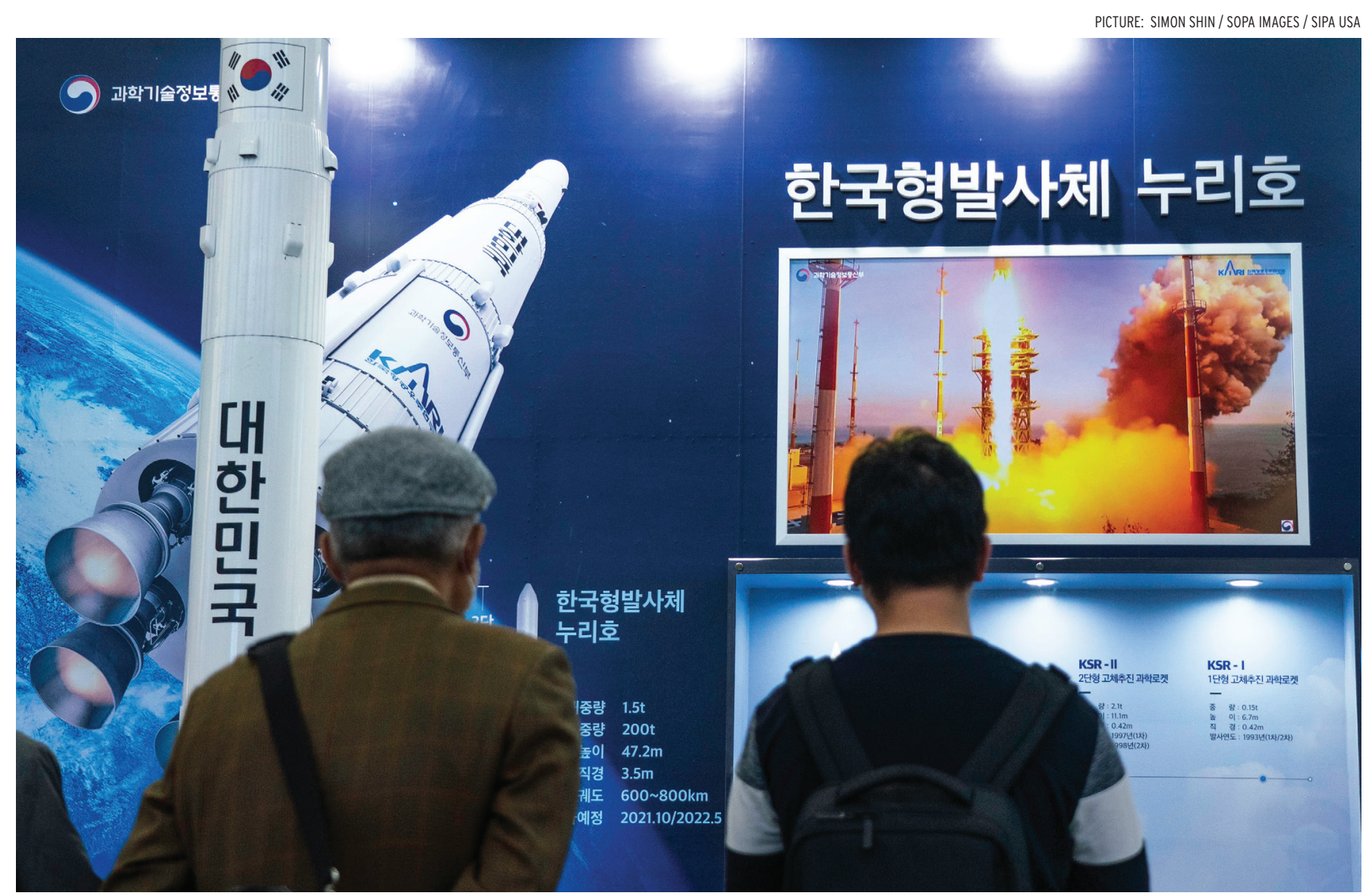

Members of the public read about South Korea's Nuri space launch vehicle test (October 2021). While the Nuri program is not linked to the military, the United Nations Security Council has sanctioned North Korea for similar launches, stating that they may contribute to the development of weapons delivery systems.

nuclear weapons of its own, South Korea recognises that conventional weapons have become more formidable against a nuclear arsenal with the advantage of higher credibility and technological advances that enable prompt response. Since 2012, the Ministry of National Defense has developed and refined military concepts including the 'Korean Air and Missile Defense', the 'Kill Chain' and the 'Korean Massive Punishment and Retaliation'. The Moon administration renamed the 'Kill Chain' and 'Korean Massive Punishment and Retaliation' the Strategic Strike System in 2018.

Revised missile guidelines resulted in rapid advancements in precisionstrike capabilities that invited queries about South Korea's nuclear latency and end goal. The main thrust of Defense Reform 2.0 has centred on force structure changes and weapons procurement. These reforms are a work in progress. There is a need for parallel advancements in qualitative military doctrine as well as in substantial C4ISR (Command, Control, Communications, Computers, Intelligence, Surveillance and Reconnaissance) capabilities. Securing stable funding and prioritising areas of investment in close consultation with the United States is also an ongoing task.

The specific timing of South Korea's targeted increase in military expenditure is a function of, but not limited to, Seoul's political determination to expedite the transfer of wartime operational control. Note that South Korea's investments in precision-strike capabilities and others were planned and initiated prior to 2017. Most certainly, the Trump administration's disrespect for alliances and the underlying change of tone in US alliance strategy heightened a sense of urgency for Seoul to take national security matters in its own hands.

South Korea harbours global aspirations to be a credible US ally and middle power. Presidents Moon and Biden declared in May 2021 that the bilateral relationship 'extends far beyond the Korean peninsula' and is 'grounded in our shared values and anchors our respective approaches to the Indo-Pacific region'. Having 
passed the brunt of the COVID-19 stress test with its digital savviness, South Korea now stands as one of the most technologically innovative, democratically resilient and economically robust states in the world.

As South Korea seeks to consolidate its security cooperation with the United States and the Indo-Pacific region, it has pledged substantial defence technology collaboration with US counterparts as well as diversification of security partnerships with like-minded states, including Australia, India and ASEAN. Despite the launch of its New Southern Policy and recently expanded New Southern Policy Plus, Southeast Asian countries remain wary of the intentions, sustainability and mercantile nature of South Korea's engagement with the region, especially as their security interests do not fully coincide with South Korea's apparent 'North Korea first' orientation.

South Korea's proactive defence drive is a testament to heightened security anxiety, a resolve to deter nuclear and other complex threats while preserving autonomy and a desire to make meaningful contributions to the Indo-Pacific security architecture. Concerns about whether South Korea's strategic initiatives align with those of the United States, whether its advanced conventional capabilities will exacerbate the perceived military imbalance on the Korean peninsula and create crisis instability, and whether a regional and potentially nuclear arms race might intensify highlight the subjective and delicate nature of the security dilemma in international relations.

South Korea needs to make a compelling case for how its military endeavours are primarily aimed to deter North Korea and can contribute to the stability of the Korean peninsula and the region. Meanwhile, the bottom line is that without a dramatic alteration in denuclearisation negotiations, North Korea will continue to drive South Korea down this path of proactive national defence.

Bo Ram Kwon is an Associate Research Fellow at the Korea Institute for Defense Analyses (KIDA).

\section{CREATIVE CONTENT}

\section{Spinning South Korean cultural industry for soft power and nation branding}

\section{CEDARBOUGH T. SAEJI}

T HAS been 10 years since Psy's

Gangnam Style catapulted to worldwide popularity. This watershed moment has been followed by many more previously inconceivable achievements by hallyu (sometimes called the Korean wave, this is a catch-all term for the international popularity of South Korean media products). As hallyu has reached around the world and captivated new audiences, a critical narrative implying hallyu is a government creation has emerged. Although it is true that the cultural industries receive governmental support, there is a difference between a government supporting a domestic industry and the government creating hallyu or being responsible for its worldwide popularity.

Most national governments aspire to support their cultural industries. Across the world, governments provide subsidies, grants and special opportunities to help launch culturemakers, hoping the investment will benefit not just the direct recipients, but also the community. Governments own and subsidise 
hallyu's success

\section{ultimately can be traced}

not to government

backing but to the

imagination and

creativity of individual

Koreans

cultural facilities and national

broadcasters, and create a climate for events because of the tremendous payoff that it offers in branding and selling their country. In theory, once a culturemaker or industry is thriving, the government will get its rewards through commerce, taxes and intangibles such as nation-branding and soft power.

In South Korea, as elsewhere, governments that support culture makers may eliminate outdated regulations, reduce red tape to streamline processes or create tax breaks for investors to stimulate industries. After South Korea democratised in 1987, the government stopped restricting potentially subversive pop culture, and by 1994 under president Kim Young-sam, began instead to promote it. This initially meant incentivising large chaebol (conglomerates) to invest in the film industry. In 1997, when the Asian financial crisis upended South Korea's economy, the IMF demanded that the chaebol divest, and many new media companies became independent-film school graduates were no longer beholden to ageing corporate executives. While the country was still labouring under the malaise of the financial crisis, H.O.T. (the first K-pop idol group) released its Chinese-language album to huge success and What Is Love (a K-drama from 1991) was broadcast on CCTV in China to record-breaking viewership.

In 1999 the Basic Law for Cultural Industries' Promotion was passed, and the predecessor to what is now called the Korea Creative Content Agency was established to promote and facilitate cultural industries-it operates primarily to provide assistance to new talent, and conduct diplomatic activities such as donating hanbok to museums or sending teams to demonstrate and teach aspects of Korean culture at overseas Korean Culture Centers. In the early 2000s hallyu industries grew rapidly. The government subsidised a few international concerts and paid the costs for exporting some television shows, in an effort to open up new markets. Hallyu experienced commercial success from dramas such as Winter Sonata and Jewel in the Palace; auteur success on the festival circuit with films by Hong Sangsoo, Im Kwontaek, and Lee Changdong; and audience adoration as the music industry became a regional powerhouse first in Northeast Asia, and then Southeast Asia. By 2006 the Korean government was looking to hallyu not just as an industry that could employ South Koreans, but as an instrument of national diplomacy.

Hallyu industries have been enormously successful at nation branding. South Korea has become a tourist destination based on its new image as a hypermodern glistening country full of romance. The economic impact of selling media products, the commercial products endorsed by its stars and the general Korean aesthetic has been substantial. Compared to its past image-derivative of the Korean War, violent protests for democracy and labour rights, and the looming threat of the North-the glittering world of K-pop and K-dramas has been an enormous boon.

W HATEVER hallyu has done for Korea, the government sometimes stands in its way. Parasite director Bong Joonho, for example, was blacklisted under president Park Geun-hye. Whilst international critics castigate hallyu for being a government creation, the industry is vulnerable to international politics. Held up as representative of Korea, hallyu essentially lost its Chinese market after 2016 when the Park Geun-hye administration accepted the construction of the US Terminal High Altitude Area Defence (THAAD) system in South Korea, angering China. As South Korea's most visible, least legally protected and least essential export product, cultural industries paid the biggest price for THAAD.

Hallyu's success has also seen direct pushback internationally. Governments in China, Russia and Turkey attack the style of masculinity modelled by K-pop stars-in China in 2021 this has extended to officially censuring Chinese artists emulating a K-pop aesthetic. Popstar performance and Korean masculinity are not the same, but by conflating them and belittling Korean masculinity, these countries seek to instruct their citizens in national modes, driving a wedge between fans with allegations of unhealthy influence and foreign ideology.

As stars are referenced in speeches and present at diplomatic events-BTS appeared alongside President Moon Jae-in as presidential envoys on a trip to the UN in September 2021-the 


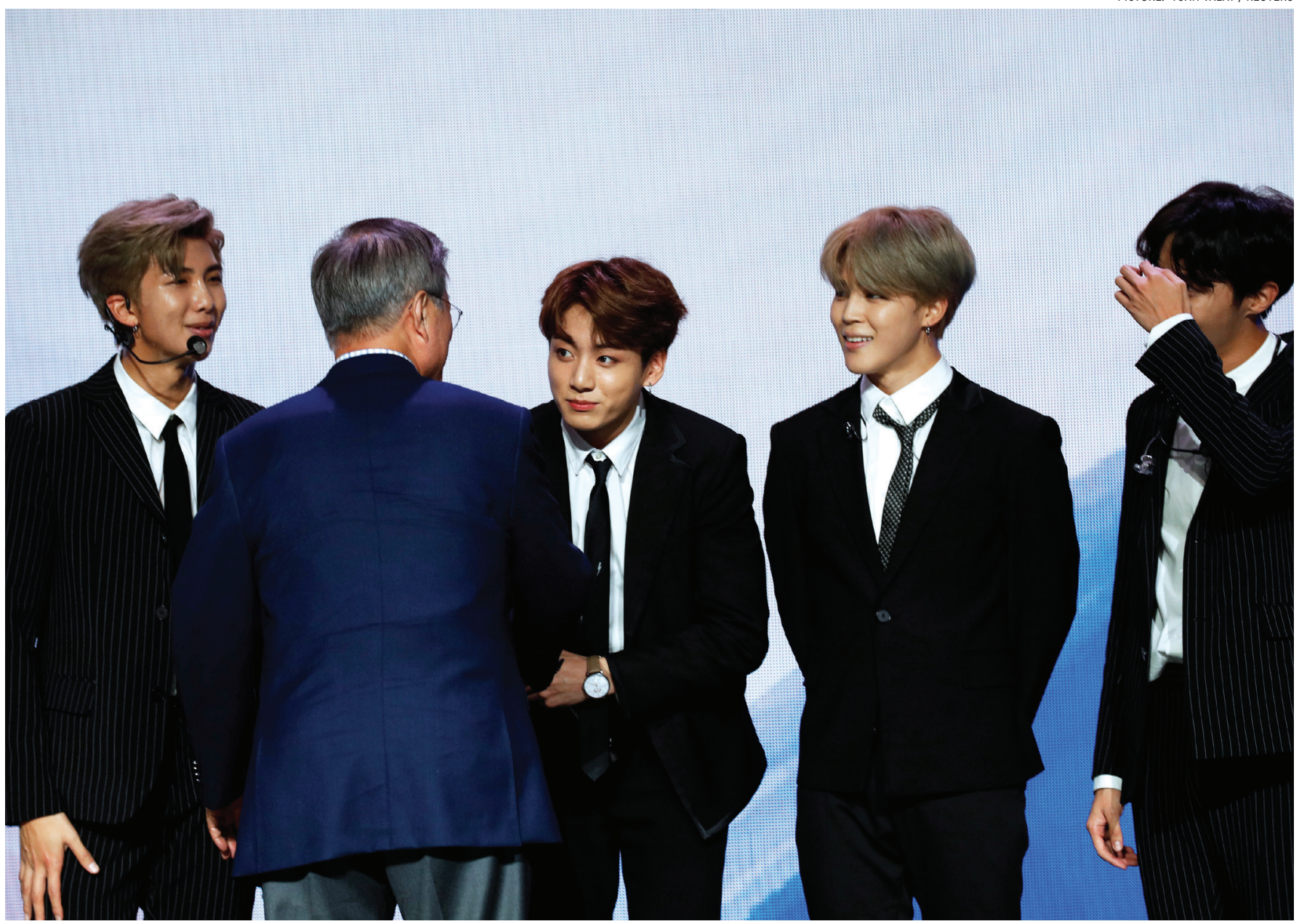

President Moon Jae-in shakes hand with the members of BTS following a performance at a Korean cultural event in Paris (0ctober 2018).

government seeks to showcase its values and policies through Korean culture. Soft power from positively regarded culture, values and policies helps South Korea achieve longterm goals. However, in deploying their draw-power the government leaves itself open to the fallibility of celebrities. Artists' actions can draw criticism and missteps by Korean celebrities may reflect on a country whose image is built on those same celebrities. The government has even less control over the actions of far-flung and well organised fan networks on international politics and diplomacy, such as K-pop fan involvement in the Trump Tulsa rally in the United States or democracy protests in Thailand.

Today, the international circulation and mediation of $\mathrm{K}$-pop culture is an important element of its production. Attracting and keeping international audiences is essential as the domestic media market is saturated, the industry has smoothly transitioned to international streaming on sites like Netflix and Spotify. Audiences are courted through giving television and film roles to K-pop idols and new music groups which tap into the magic of BTS are created by producers.

These safer approaches built on past success exist, but there are visionaries too. Nothing about Psy or Gangnam Style followed the conventional 2012 K-pop formula, BTS was created with a fresh approach by a new agency and Squid Game director Hwang Donghyuk could not find domestic backing for his show. Now that Squid Game and Parasite have won international acclaim, upcoming Netflix projects seem to project a darker image of Korea. Staying nimble and open to possibilities has been the source of the biggest hits.

This is no fluke: hallyu's success ultimately can be traced not to government backing but to the imagination and creativity of individual Koreans. EAFQ

CedarBough T Saeji is Assistant Professor of Korean and East Asian Studies at Pusan National University. 


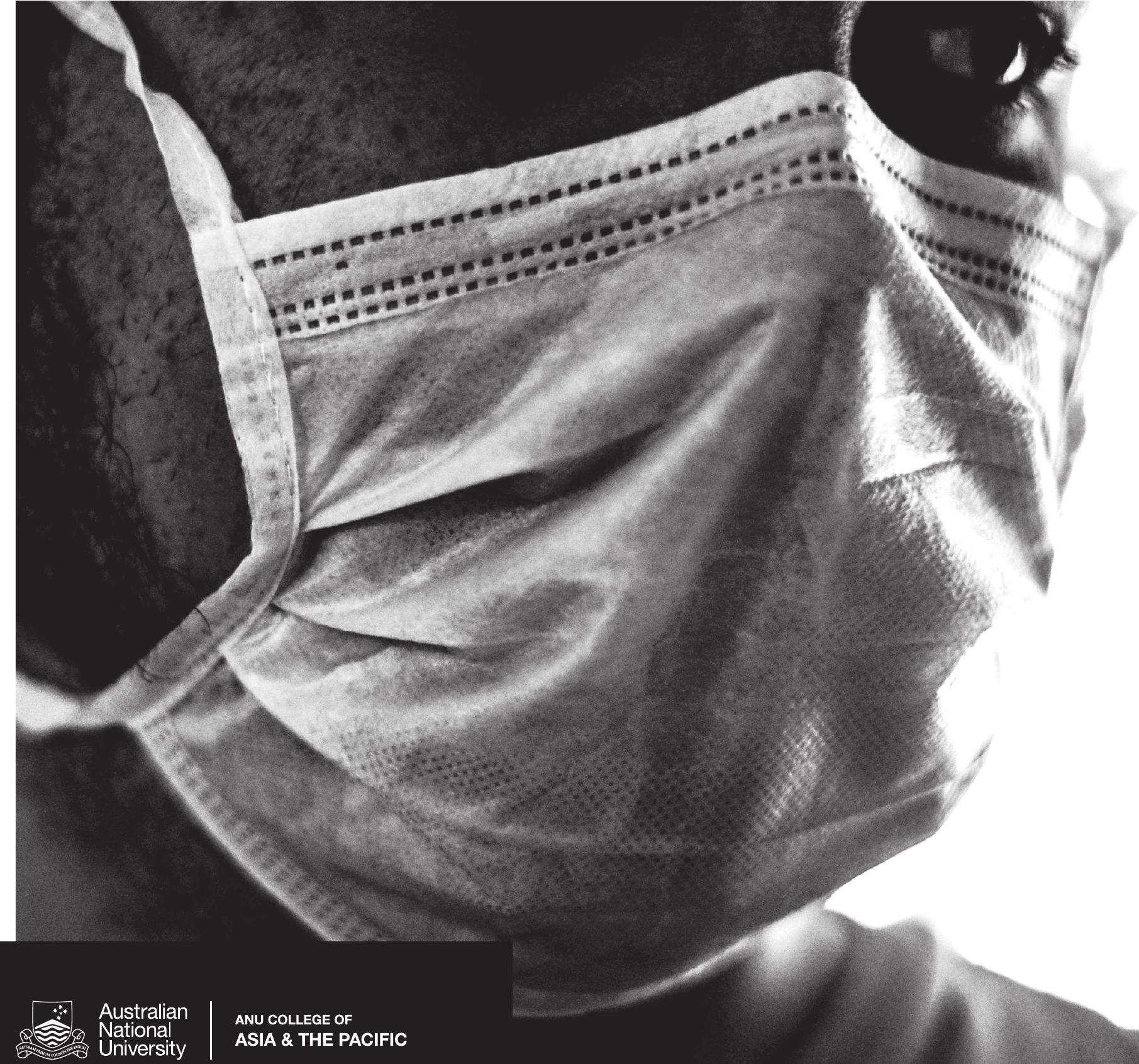

\section{There has never been a more urgent time to use research to shape public debate, policy decisions and the well-being of our society.}

